\title{
Financial Constraints, Stock Liquidity, and Stock Returns
}

\section{September 2019}

\begin{abstract}
This paper examines stock liquidity in explaining the mixed relations between financial constraints and stock returns and the pricing of stock liquidity across financially constrained and unconstrained firms. We find a negative relation in liquid portfolios and a positive relation in illiquid portfolios. Financially constrained firms have higher liquidity risk and earn a higher illiquidity premium than unconstrained firms. Financial constraints cannot be independently priced in stock returns and can only be priced in conjunction with stock liquidity in bad economic times. Stock liquidity is independently priced for financially constrained firms or in good times, but not for unconstrained firms.
\end{abstract}

JEL classification: G12; G14; G32

Keywords: Asset pricing; financial constraints; stock liquidity; macroeconomic conditions. 


\section{Introduction}

Modern finance theory suggests that investors demand higher returns for holding stocks with higher risk. Consistent with this view, Gomes et al. (2006), Whited and Wu (2006), and Livdan et al. (2009) find that financially constrained firms are riskier and generate higher returns than unconstrained firms. Conversely, Lamont et al. (2001) report that financially constrained firms earn lower returns than unconstrained firms and this relation cannot be explained by monetary policy and credit conditions. Campello and Chen (2010) attribute the mixed relations between financial constraints and stock returns to macroeconomic conditions, while Li (2011) finds that the financial constraints-return relation is strengthened by the firm's research and development $(\mathrm{R} \& \mathrm{D})$ intensity. However, there is no consensus on the explanation for the mixed relations in the literature. On the other hand, although the pricing of stock liquidity has been extensively studied, ${ }^{1}$ there is surprisingly little empirical research on how the pricing of stock liquidity is affected by financial constraints. Our work addresses the research gap in the literature.

In this study, we examine whether the mixed relations between financial constraints and stock returns are associated with stock liquidity and the pricing of stock liquidity across financially constrained and unconstrained firms. Financial constraints and stock liquidity are likely to be highly correlated with each other. Intuitively, financially constrained firms tend to be small and illiquid firms, while unconstrained firms are typically large and liquid firms. As a result, financially constrained firms are likely to have higher liquidity risk than unconstrained

\footnotetext{
${ }^{1}$ See, for example, Amihud and Mendelson (1986), Brennan and Subrahmanyan (1996), Amihud (2002), Easley et al. (2002), Acharya and Pedersen (2005), Liu (2006), and Sadka (2006).
} 
firms, and illiquid firms are expected to have more financial constraints than liquid firms. We, therefore, conjecture that financially constrained firms should earn a higher illiquidity premium than unconstrained firms and that the financial constraint premiums could differ between liquid and illiquid firms. Moreover, we expect that there is an interaction effect between financial constraints and stock liquidity on stock returns and that the effect varies over the business cycle.

Our hypotheses are motivated by three strands of the literature. First, both financial constraints and stock liquidity are highly related to asymmetric information. Financial constraints are associated with a firm's supply of capital ${ }^{2}$ and the opportunity cost of internal capital and its external cost of capital (Fazzari et al., 1988). Greenwald et al. (1984) and Myers and Majluf (1984) document that asymmetric information can increase the cost of raising external equity since potential buyers with limited information are unwilling to pay higher prices. Morellec and Schürhoff (2011) demonstrate that financially constrained firms have a higher degree of asymmetric information than unconstrained firms. Moreover, a substantial body of literature finds that asymmetric information reduces stock liquidity due to higher adverse selection costs and lower trading volume. ${ }^{3}$ Therefore, financial constraints are likely to be correlated with stock liquidity due to asymmetric information.

Second, the existing literature shows that stock liquidity has strong links with the proxies of financial constraints. For instance, Amihud and Mendelson (1986) and Amihud (2002) show

\footnotetext{
${ }^{2}$ See, for example, Stiglitz and Weiss (1981) Almeida and Campello (2004), and Whited and Wu (2006)

${ }^{3}$ See, for example, Glosten and Milgrom (1985), Kyle (1985), Easley and O'Hara (1987), Admati and Pfeiderer (1988), Glosten and Harris (1988), Brennan and Subrahmanyan (1995), Eastley et al. (1996), and Kelly and Ljungqvist (2012).
} 
that stock liquidity is positively related to firm size. Banerjee et al. (2007) find that stock liquidity influences a firm's dividend policy. Odders-White and Ready (2006) and Gopalan et al. (2012) demonstrate that firms with good credit ratings are likely to be liquid firms. Bulter et al. (2005) report that stock market liquidity plays an important role in determining the cost of raising external capital. Mazouz et al. (2014) also show that the cost of equity capital is associated with systematic liquidity risk. Since both financial constraints and stock liquidity have the impacts on stock returns, they are likely to have an interaction effect on stock returns.

Third, from an economic stance, Kiyotaki and Moore (1997) theoretically show that credit constraints amplify business cycle fluctuations and impact asset prices. Gertler and Gilchrist (1994), Kashyap et al. (1994), Campello and Chen (2010), and Campello et al. (2010) document that financially constrained firms bind more during recessions than during expansions because of a deterioration in credit, which leads to differences in stock returns across financially constrained and unconstrained firms over the business cycle. Change et al. (2019) also find macroeconomic conditions have an impact on financial constraints and firms' financing decisions. Moreover, Næs et al. (2011) show that aggregate stock liquidity is a good indicator of the real economy and changes with the business cycle. As both financial constraints and stock liquidity are affected by business conditions, we expect that the interaction effect between financial constraints and stock liquidity on stock returns changes with the business cycle. 
There has been considerable debate in the literature regarding the best measure of financial constraints. ${ }^{4}$ In this study, we follow Dasgupta et al. (2019) and employ four firm characteristic measures of asset size, dividend payout, bond rating, and commercial paper rating, and two index measures of the WW index (Whited and Wu, 2006) and HP index (Hadlock and Pierce, 2010) as proxies for financial constraints. The firm characteristic measures capture the individual dimension of financial constraints in a firm's vulnerability to capital market imperfection, funding situation, and accessibility to the public debt markets. The WW and HP indices capture different dimensions of financial constraints and avoid the problems of sample selection, simultaneity, and measurement-error (Whited and Wu, 2006; Hadlock and Pierce, 2010). Farre-Mensa and Ljungqvist (2016) report that based on the individual firm characteristic, WW, and HP indices measures, financially constrained firms show strong commonalities. We exclude the commonly used KZ index measure (Kaplan and Zingales,1997) because the measure is difficult to capture the variation of financial constraints across firms and over time, and is subject to have measurement errors (Whited and Wu, 2006; Farre-Mensa and Ljungqvist, 2016). We compute three stock illiquidity measures; these are the bid-ask spread of Amihud and Mendelson (1986), the price impact measure of Amihud (2002), and the turnover of Datar et al. (1998). Then, following Korajczyk and Sadka (2008), we estimate the first principal component of three individual stock liquidity measures to capture multiple dimensions of stock liquidity.

\footnotetext{
${ }^{4}$ See for example, Kaplan and Zingales (1997), Whited and Wu (2006), Hadlock and Pierce (2010), Bodnaruk et al. (2015), Hoberg and Maksimovic (2015), Farre-Mensa and Ljungqvist (2016), and Schauer et al. (2019).
} 
We find that financially constrained firms have higher liquidity risk and earn higher illiquidity premiums than unconstrained firms. Furthermore, the financial constraint premiums are significantly negative for liquid portfolios and are positive for illiquid portfolios. Consistent with our hypothesis, there is a strong interaction effect between financial constraints and stock liquidity on stock returns. With only a few exceptions, the interaction effect is strong in bad economic times and weak in good economic times. We also find that stock liquidity is independently priced in the cross-section of stock returns for financially constrained firms or in good times, but it is not independently priced for financially unconstrained firms.

The effects of financial constraints on firm behavior are important issues in corporate finance. A number of studies have demonstrated that financial constraints have a strong impact on firms' investment behavior (Fazzari et al.,1988; Gilchrist and Himmelberg, 1995; Hennessy and Whited, 2007; Campello et al., 2010); cash holdings (Denis and Sibikov, 2010); R\&D investment (Li, 2011); stock repurchase decisions (Chen and Wang, 2012); cash tax savings and income shifting (Dyreng and Markle, 2016; Edwards et al., 2016); merger and acquisition activities (Greene, 2017); accounting information quality (Kurt, 2018); inventory behavior (Dasgupta et al., 2019); and firm productivity (Jin et al., 2019). Moreover, Haider et al. (2018) demonstrate that financial constraints are affected by government ownership and also influence firms' performance. Therefore, a better understanding of the interaction effect between financial constraints and stock liquidity is important not only for investors but also for decision-makers within corporations. 
This paper differs from prior studies in financial constraints and stock liquidity in two aspects. First, the existing financial constraints literature mainly examines the relation between financial constraints and stock returns of all stocks. ${ }^{5}$ Little empirical research has addressed the impact of stock liquidity on this relation. Our study adds to the literature by exploring a novel interaction effect between financial constraints and stock liquidity on stock returns. We shed light on the mixed relations between financial constraints and stock returns in the literature that are associated with stock liquidity. Our findings have an important implication for investors in that the premium earned from financially constrained firms is compensation for taking on higher liquidity risk rather than the risk of financial constraints.

Second, numerous studies have reported that stock liquidity is systematically priced in the cross-section of stock returns. ${ }^{6}$ However, whether the pricing of stock liquidity varies with financial constraints and macroeconomic conditions has not been comprehensively explored. We contribute to the literature by analyzing the pricing separately for financially constrained and unconstrained firms, and under different macroeconomic conditions. Our findings provide new insight into asset pricing that the pricing of stock liquidity is dominated by financially constrained firms or good economic conditions.

The remainder of this paper is organized as follows. Section 2 develops the theoretical link between financial constraints, stock liquidity, liquidity risk, and stock returns. Section 3 describes the data, the proxies for financial constraints, and the measures of liquidity. Section 4 presents the empirical results, and Section 5 provides some concluding remarks.

\footnotetext{
${ }^{5}$ See for example, Lamont et al. (2001), Gomes et al. (2006), Whited and Wu (2006), Livdan et al. (2009).

${ }^{6}$ See footnote 1.
} 


\section{The links between financial constraints, stock liquid- ity, liquidity risk, and stock returns}

In this section, we begin with the discussion on the connection between financial constraints and stock liquidity through asymmetric information. We further explore the relation between financial constraints and expected stock returns on an investment-based asset pricing model. Next, we discuss the relation between stock liquidity, liquidity risk, and expected stock returns based on a liquidity-adjusted capital asset pricing model (liquidity-adjusted CAPM). Finally, we develop our hypothesis by interlinking financial constraints, stock liquidity, liquidity risk, and stock returns.

\subsection{Related literature about asymmetric information with financial constraints and stock liquidity}

The impact of asymmetric information on corporate investment has been extensively studied in the literature. Jaffee and Russell (1976) and Stiglitz and Weiss (1981) show that external debt finance is more costly than internal funds due to an adverse selection problem documented by Akerlof (1970). Greenwald et al. (1984) and Myers and Majluf (1984) argue that the adverse selection problem makes external equity finance even more expensive because stock issues convey bad news and lead to a decline in stock price and an increase in issue costs. Morellec and Schürhoff (2011) extend this body of work and show that the adverse selection problems are more severe for financially constrained firms, which significantly affects the value, the cost of external capital, and investment behavior of financially constrained firms. 
On the other hand, a number of studies have documented that asymmetric information impacts stock liquidity. For example, Glosten and Milgrom (1985), Kyle (1985), Easley and O'Hara (1987), Admati and Pfeiderer (1988), Glosten and Harris (1988), and Brennan and Subrahmanyan (1995) show that the adverse selection problem in the marketplace can decrease stock liquidity, which can be captured by price impact and trading volume. Easley et al. (1996) propose a measure of the probability of information-based trading that reflects the adverse selection cost due to asymmetric information between traders. They find a negative relation between the probability of information-based trading and liquidity for infrequentlytraded stocks. Diamond and Verrecchia (1991) use disclosure of private information as a proxy for reducing information asymmetry. They show that reducing information asymmetry can increase a firm's liquidity and reduce its cost of capital. Kelly and Ljungqvist (2012) document that stock liquidity is the major link between information asymmetry and share prices. Overall, research findings indicate that financial constraints are likely to be highly correlated with stock liquidity because both are heavily influenced by asymmetric information.

\subsection{The investment-based model with financial constraints}

Gomes et al. (2006) and Whited and Wu (2006) develop the investment-based model with financial constraints as follows,

$$
R_{i, t+1}^{I}=\frac{\left(1+\lambda_{i, t+1}\right)\left\{\Pi_{K}\left(K_{i, t+1}, X_{i, t+1}\right)-\Phi_{K}\left(I_{i, t+1}, K_{i, t+1}\right)+\left(1-\theta_{i}\right)\left[\Phi_{I}\left(I_{i, t+1}, K_{i, t+1}\right)+1\right]\right\}}{\left(1+\lambda_{i, t}\right)\left[\Phi_{I}\left(I_{i, t}, K_{i, t}\right)+1\right]},
$$


where $R_{i, t+1}^{I}$ is the investment return from $t$ to $t+1, \lambda_{i, t}$ is the Lagrange multiplier associated with the constraint which can be interpreted as the shadow cost of external capital, $\Pi\left(K_{i, t}, X_{i, t}\right)$ is the available funds function $\left(\Pi_{K}>0\right), K_{i, t}$ is the capital stock at time $t, X_{i, t}$ is a vector of exogenous shocks, $\Phi\left(I_{i, t}, K_{i, t}\right)$ is the adjusted cost function $\left(\Phi_{I}>0, \Phi_{K}<0\right.$, and $\left.\Phi_{I I}>0\right), I_{i, t}$ is the investment during time $t$, and $\theta$ is the capital depreciation rate. More-

over, $\frac{1+\lambda_{i, t+1}}{1+\lambda_{i, t}}$ represents the relative shadow cost of external capital, which reflects the role of financing frictions, when $\lambda_{i, t+1}=\lambda_{i, t}$, financing frictions have no impact on the investment return $R^{I}$. Equation (1) indicates that the investment return is highly related to the relative shadow cost of external capital. Also, financial constraints can only affect investment returns if they are time-varying, where $\lambda_{i, t+1} \neq \lambda_{i, t}$.

\subsection{The liquidity-adjusted capital asset pricing model}

Acharya and Pedersen (2005) derive the liquidity-adjusted CAPM that captures three forms of liquidity risk: the commonality in liquidity of Chordia et al. (2000), the sensitivity of stock return to the market liquidity of Pastor and Stambaugh (2003), and the sensitivity of stock liquidity to market returns, which can be specified as follows,

$$
E\left[R_{i, t+1}-R_{f, t+1}\right]=E\left[t c_{i, t+1}\right]+E\left[R_{m, t+1}-t c_{m, t+1}-R_{f, t+1}\right]\left(\beta_{1}+\beta_{2}+\beta_{3}+\beta_{A P}\right),
$$

where $R_{i, t+1}$ is the gross return before transaction costs on stock $i, R_{f, t+1}$ is the risk-free rate, $t c_{i, t+1}$ is the relative time-varying transaction costs on stock $i$ and represents stock liquidity, $R_{m, t+1}$ is the market gross return before transaction costs, $t c_{m, t+1}$ is the relative time-varying transaction costs on all stocks in the market and represents market liquidity, 
$\beta_{1}=\frac{\operatorname{Cov}\left(R_{i, t+1}, R_{m, t+1}\right)}{\operatorname{Var}\left(R_{m, t+1}-t c_{m, t+1}\right)}$ represents the market risk, $\beta_{2}=\frac{\operatorname{Cov}\left(t c_{i, t+1}, t c_{m, t+1}\right)}{\operatorname{Var}\left(R_{m, t+1}-t c_{m, t+1}\right)}$ represents the commonality in liquidity of stock $i, \beta_{3}=\frac{\operatorname{Cov}\left(-R_{i, t+1}, t c_{m, t+1}\right)}{\operatorname{Var}\left(R_{m, t+1}-t c_{m, t+1}\right)}$ represents the liquidity risk as the sensitivity of stock returns to the market liquidity, and $\beta_{A P}=\frac{\operatorname{Cov}\left(-t c_{i, t+1}, R_{m, t+1}\right)}{\operatorname{Var}\left(R_{m, t+1}-t c_{m, t+1}\right)}$ represents the liquidity risk of Acharya and Pedersen (2005) as the sensitivity of stock liquidity to market returns.

\subsection{The links between financial constraints, stock liquidity, liquid-}

\section{ity risk, and stock returns}

Combining Equations (1) and (2), we can have

$$
\begin{aligned}
E\left[R_{i, t+1}\right] & =R_{f, t+1}+E\left[t c_{i, t+1}\right]+E\left[R_{m, t+1}-t c_{m, t+1}-R_{f, t+1}\right]\left(\beta_{1}+\beta_{2}+\beta_{3}+\beta_{A P}\right) \\
& =\frac{\left(1+\lambda_{i, t+1}\right)\left\{\Pi_{K}\left(K_{i, t+1}, X_{i, t+1}\right)-\Phi_{K}\left(I_{i, t+1}, K_{i, t+1}\right)+\left(1-\theta_{i}\right)\left[\Phi_{I}\left(I_{i, t+1}, K_{i, t+1}\right)+1\right]\right\}}{\left(1+\lambda_{i, t}\right)\left[\Phi_{I}\left(I_{i, t}, K_{i, t}\right)+1\right]} .
\end{aligned}
$$

According to Equation (3), holding everything else fixed, the stock liquidity $\left(t c_{i, t+1}\right)$, the commonality in liquidity $\left(\beta_{2}\right)$, and the liquidity risks $\left(\beta_{3}\right.$ and $\left.\beta_{A P}\right)$ of stock $i$ are closely related to financial constraints, measured by $\frac{1+\lambda_{i, t+1}}{1+\lambda_{i t}} \cdot{ }^{7}$ Financial constraints capture investment friction on the firms' side, while stock liquidity captures trading frictions on the investors' side. Empirical findings show that they are likely to be highly correlated and both of them have an impact on stock returns. We, therefore, hypothesize that there is an interaction effect between financial constraints and stock liquidity on stock returns.

\footnotetext{
${ }^{7}$ According to Gomes et al. (2006) and Whited and Wu (2006), $\frac{1+\lambda_{i, t+1}}{1+\lambda_{i t}}$ is related to the shadow cost of the constraint today, relative to tomorrow. They emphasize the cyclical role of financial constraints in asset pricing.
} 


\section{$3 \quad$ Data and Measures}

Following Fazzari et al. (1988), our sample consists of manufacturing firms (SIC codes between 2000 and 3999) traded on the NYSE, AMEX, and NASDAQ for the period 19752017. We collect annual firm-level accounting data from the COMPUSTAT database annual files and use Standard \& Poor's $(S \& P)$ Long-term and Short-term Domestic Issuer Credit Ratings as bond and commercial paper ratings. The ratings are available on COMPUSTAT from 1985. We also obtain the monthly stock returns and daily data for estimating stock liquidity from the Center for Research in Security Prices (CRSP). The CRSP delisting returns have been adjusted in our dataset. For stocks without the CRSP delisting returns, we follow the method of Shumway (1997). We extract the monthly return series of the Fama-French three factors from Kenneth French's website. ${ }^{8}$ The return series of the liquidity risk factor of Sadka (2006) is obtained from Sadka's website, ${ }^{9}$ and the rates of a ten-year Baa bond and a one-year Treasury bill are taken from the Federal Reserve Board.

\subsection{Proxies for financial constraints}

Following Almeida et al. (2004), Faulkender and Wang (2006), Hahn and Lee (2009), and Dasgupta et al. (2019), we use the following four firm characteristic measures and the WW and HP indices as proxies for financial constraints.

(i) Asset size $(A T)$ : Small firms are likely to have higher costs of financial distress, agency costs, and asymmetric information than large firms have. Therefore, they face more

\footnotetext{
${ }^{8}$ http://mba.tuck.dartmouth.edu/pages/faculty/ken.french/

${ }^{9}$ https://www2.bc.edu/ronnie-sadka/
} 
constraints in raising external capital. We measure asset size as the book value of total assets (data item $A T$ ). Following Li and Zhang (2010), at the end of June of each year $t$, we rank all firms into terciles based on their asset size for the fiscal year ending in the calendar year $t-1$. We classify firms in the bottom tercile of the asset size distribution as financially constrained firms, and those in the top tercile as unconstrained firms.

(ii) Payout ratio $(P R)$ : Fazzari et al. (1988) show that financially constrained firms tend to pay low dividends because dividends and investment use funds competitively. In addition, constrained firms are unlikely to produce sufficient internal funds to meet their investment requirements. Appendix A provides a detailed calculation of the payout ratio. At the end of June of each year $t$, we rank all firms into terciles based on their payout ratios for the fiscal year ending in the calendar year $t-1$. We classify firms in the bottom tercile of the payout distribution as financially constrained firms, and those in the top tercile as financially unconstrained firms. ${ }^{10}$

(iii) Long-term bond rating $(B R)$ : Firms with a long-term bond rating can issue public debts and face fewer financial constraints than those without do. We classify firms that have positive debt but have no $S \& P$ long-term bond rating during our sample period as financially constrained firms, and those that have positive debt and $S \& P$ long-term bond rating as financially unconstrained firms. We then define $B R$ as zero for constrained firms and one for unconstrained firms.

\footnotetext{
${ }^{10}$ Following Hahn and Lee (2009), when sorting firms based on their payout ratio, we exclude firms with zero payout or negative net income. Then, we assign those firms with zero payout or negative net income to the constrained firms.
} 
(iv) Commercial paper rating $(C R)$ : Like long-term bond rating, firms without a commercial paper rating are unable to issue short-term public debt because of their higher default risk. We classify firms that have positive debt but have no $S \& P$ commercial paper rating during our sample period as financially constrained firms, and those that have positive debt and $S \& P$ commercial paper rating as financially unconstrained firms. We define $C R$ as zero for constrained firms and one for unconstrained firms.

(v) WW index $(W W)$ is calculated by a linear combination of firm characteristics following Whited and Wu (2006). Appendix B describes full construction for the WW index of a firm. At the end of June of each year $t$, we rank all firms into terciles based on their $W W$ index for the fiscal year ending in the calendar year $t-1$. We classify firms in the top tercile as financially constrained firms, and those in the bottom tercile as financially unconstrained firms.

(vi) HP index $(H P)$ is computed by a linear combination of asset size and age following Hadlock and Pierce (2010). Appendix B describes complete construction for the $H P$ index of a firm. At the end of June of each year $t$, we rank all firms into terciles based on their HP index for the fiscal year ending in the calendar year $t-1$. We classify firms in the top tercile as financially constrained firms, and those in the bottom tercile as financially unconstrained firms. 


\subsection{Measures of stock liquidity}

We employ three individual liquidity measures of the quoted bid-ask spread, price impact, and turnover ratio. We calculate each measure as the average of the daily measures over the prior 12 months. We also estimate the first principal component of three individual liquidity measures following Korajczyk and Sadka (2008).

(i) Quoted bid-ask spread $(B A)$ is the difference between the ask and bid prices on a particular day divided by the average ask and bid prices on that day. ${ }^{11}$ Stocks with high $B A$ are illiquid because of their high transaction costs.

(ii) Price impact $(P I)$ is the daily absolute return-to-dollar-volume ratio. The price impact of a stock reflects the response of the transaction price to the trading volume and captures the liquidity effects of asymmetric information. ${ }^{12}$ Stocks with high PI are illiquid since their transaction prices respond more to trading volume.

(iii) Turnover ratio $(T O)$ is the ratio of the number of shares traded to the number of shares outstanding. Turnover ratio captures trading frequency. Stocks with high TO are more liquid than stocks with low $T O \cdot{ }^{13}$

\footnotetext{
${ }^{11}$ For NYSE/AMEX stocks, the CRSP daily bid and ask prices are the closing bid and closing ask prices on the day, whereas NASDAQ uses the inside quotation as the bid and ask prices. When the bid or ask prices of a stock are not available on a day, we use Bid or Low price, or Ask or High price from the CRSP as the bid and ask prices for the stock, respectively. Due to the limited availability of bid and ask prices, the $B A$ measure is calculated based on available bid and ask prices in the prior 12 months.

${ }^{12}$ Hasbrouck (2009) and Goyenko et al. (2009) report that $B A$ and $P I$ estimated using the low-frequency CRSP data are highly correlated with those using high-frequency data from the Trade and Quote (TAQ) Database and the Securities and Exchange Commission (SEC) Rule 605.

${ }^{13}$ Similar to Amihud (2002), we calculate $P I$ by requiring it to have at least $80 \%$ non-missing daily trading volumes available in the prior 12 months. Also, we exclude zero trading volume over the prior 12 months. To construct TO, we require no missing daily trading volumes in the prior 12 months following Liu (2006).
} 
(iv) The principal component of liquidity $(P C L I Q)$ is the first principal component of three individual liquidity measures, including quoted bid-ask spread, price impact, and negative turnover ratio. Stocks with high $P C L I Q$ are less liquid than stocks with low PCLIQ .

\subsection{Measures of liquidity risk}

In this study, we use two liquidity risk measures of Sadka (2006) and Acharya and Pedersen (2005).

(i) The Sadka (2006) liquidity risk measure, $\beta_{\text {Sadka }}$, is estimated as the sensitivity of stock returns to unexpected changes in market liquidity. Sadka (2006) develops the liquidity risk factors based on the transitory-fixed and permanent-variable components of price impact. The fixed component of price impact is driven by a transitory price change in response to market-making costs. The variable component is due to a permanent price change that is related to a change in its perceived intrinsic value. The fixed and variable liquidity risk factors are based on the innovations of the market-wide components.

(ii) The Acharya and Pedersen (2005) liquidity risk measure, $\beta_{A P}$, is computed as the sensitivity of stock liquidity to market returns. Acharya and Pedersen (2005) derive this measure from their liquidity-adjusted CAPM in Equation (2).

Table 1 provides descriptive statistics and the correlation coefficients across the proxies of financial constraints and the measures of stock liquidity. The means of bond rating $(B R)$ and 
commercial paper rating $(C R)$ suggest that, on average, only $37.1 \%$ and $14.7 \%$ of manufacturing firms have a bond and commercial paper ratings, respectively, so they are financially unconstrained firms. The $W W$ and $H P$ indices are negatively correlated with asset size $(A T)$, with the correlation coefficients of -0.852 and -0.89 , indicating that firms with high $W W$ or HP indices have small asset size. Consistent with Li and Zhang (2010) and Lam and Wei (2011), the constraint proxies of $A T$, payout ratio $(P R), B R$, and $C R$ are negatively correlated with the stock liquidity measures of quoted bid-ask spread $(B A)$, price impact $(P I)$, and principal component of liquidity $(P C L I Q)$, while $W W$ and $H P$ are positively correlated with these liquidity measures. The results suggest that financially constrained firms are illiquid. In other words, trading on firms with small asset size, low payout ratio, without bond and commercial paper ratings, or firms with high $W W$ and $H P$ indices is characterized by large transaction costs with high bid-ask spread, price impact, and principal component of liquidity.

\section{Empirical Results}

\subsection{Descriptive analysis of financially constrained and unconstrained}

\section{firms}

Table 2 presents summary statistics on various firm characteristics of financially constrained and unconstrained firms under each of the six proxies. The letter $\mathrm{U}$ represents the financially unconstrained group that contains firms in the top tercile of $A T$ or $P R$, firms in the bottom tercile of $W W$ or $H P$, or firms that have $B R$ or $C R$. The letter $\mathrm{C}$ represents the constrained group that contains firms in the bottom tercile of $A T$ or $P R$, or firms in the 
top tercile of $W W$ or $H P$, or firms that have no $B R$ or $C R$. Appendix A provides detailed descriptions of firm characteristics. In line with a number of studies, financially constrained firms tend to be small and value firms with lower market value $(M V)$ and higher book-tomarket ratio $(B / M) .{ }^{14}$ They have more investment opportunities (higher Tobin's $Q$ ) but generate lower cash flows (negative $C F$ ) and profits from their operations $(P F)$. Moreover, constrained firms have substantially higher standard deviations $(S D)$ of $C F$ and $P F$ than those of unconstrained firms. As a result, they are likely to be difficult to raise debt capital, and therefore, they hold more cash $(\mathrm{CH})$. On the other hand, unconstrained firms have more tangible assets $(T A)$ and produce higher profits. They borrow more debt with higher leverage $(B L)$ except for unconstrained $P R$ firms, indicating that unconstrained firms have lower financial distress costs and follow the trade-off theory in making their capital structure decisions.

Table 3 reports the return performance and the measures of stock liquidity and liquidity risk for financially constrained and unconstrained firms. C-U represents the difference in the estimated variables between the constrained and unconstrained groups. Panel A presents the monthly average excess returns and abnormal returns. The excess return is the return that subtracts the risk-free rate from the raw return. The abnormal return (FF3 alpha) is the intercept of the Fama and French (1993) three-factor model (hereafter FF3) as follows,

$$
R_{i, t}-R_{f, t}=\alpha_{i}+\beta_{i, M K T}\left(R_{m, t}-R_{f, t}\right)+s_{i} S M B_{t}+h_{i} H M L_{t}+\varepsilon_{i, t}
$$

\footnotetext{
${ }^{14}$ See, for example, Fazzari et al. (1988), Almeida et al. (2004), Faulkender and Wang (2006), Denis and Sibilkov (2009), Hahn and Lee (2009), Livdan et al. (2009), and Hadlock and Pierce (2010).
} 
where $R_{i, t}$ is the return on stock $i$ in month $t, R_{f, t}$ is the one-month Treasury bill rate, and $R_{m, t}$ is the value-weighted market return on all stocks listed on the NYSE, AMEX, and NASDAQ. $S M B_{t}$ (small-minus-big) and $H M L_{t}$ (high-minus-low) are the returns on the mimicking portfolios for size and book-to-market equity.

Panel A of Table 3 shows that the return patterns of financially constrained and unconstrained firms vary depending on the proxies of financial constraints. For instance, financially constrained $A T, W W$, and $H P$ firms have higher excess returns and FF3 alphas than unconstrained $A T, W W$, and $H P$ firms, while constrained $B R$ and $C R$ firms have lower excess returns and FF3 alphas than unconstrained corresponding firms, but most of them are statistically insignificant. The results are in line with the empirical findings on the mixed relations between financial constraints and stock returns reported by the literature. ${ }^{15}$ The results in Panel B of Table 3 suggest that financially constrained firms tend to be illiquid firms with higher bid-ask spread $(B A)$, price impact $(P I)$, and principal component of liquidity $(P C L I Q)$, while unconstrained firms are liquid firms with lower $B A, P I$, and $P C L I Q$. For instance, financially unconstrained $A T$ firms have an average $B A$ of $1.57, P I$ of 0.23 , and $P C L I Q$ of -0.36 , while constrained $A T$ firms have an average $B A$ of $8.65, P I$ of 17.67 , and PCLIQ of 0.47 .

\footnotetext{
${ }^{15}$ We also follow Campello and Chen $(2010)$ and estimate a composite financial constraint measure based on six financial constraint proxies of $A T, P R, B R, C R, W W$, and $H P$. We find that financially constrained portfolio significantly outperforms unconstrained portfolio based on the composite financial constraint measure.
} 
Clearly, the degree of stock liquidity is different between financially constrained and unconstrained firms. We, therefore, investigate liquidity risk for financially constrained and unconstrained firms. The liquidity risk measure, $\beta_{\text {Sadka }}$, is estimated as follows,

$$
R_{i, t}-R_{f, t}=\alpha_{i}+\beta_{i, M K T}\left(R_{m, t}-R_{f, t}\right)+\beta_{i, \text { Sadka }} L I Q_{\text {Sadka }, t}+\varepsilon_{i, t},
$$

where $L I Q_{\text {Sadka,t }}$ denotes the Sadka's (2006) liquidity factor based on the fixed component of price impact.

Panel $\mathrm{C}$ of Table 3 reports $\beta_{i, \text { Sadka }}$ and $\beta_{i, A P}$ for financially constrained and unconstrained firms. The results show that constrained firms have a higher magnitude of liquidity risk than unconstrained firms. For example, $\beta_{i, \text { Sadka }}$ and $\beta_{i, A P}$ are, respectively, 1.79 and 0.37 for financially unconstrained $A T$ firms, while they are 4.73 and 3.04 for constrained $A T$ firms.

The results in Table 3 suggest that financially constrained firms have higher liquidity risk in terms of $\beta_{i, S a d k a}$ and $\beta_{i, A P}$ than unconstrained firms. Acharya and Pedersen (2005) show that the commonality in stock liquidity documented by Chordia et al. (2000) and Hasbrouck and Seppi (2001) is another important form of liquidity risk. We then further explore liquidity commonality across financially constrained and unconstrained firms. Following Acharya and Pedersen (2005), we estimate the liquidity commonality $\left(\beta_{2}\right)$ as the sensitivity of stock liquidity to market liquidity from the following equation,

$$
u_{i, m}=b_{0}+\beta_{2} u_{M K T, m}+e_{i, m},
$$


where $u_{i, m}$ denotes the liquidity innovation of an individual stock or a portfolio $i$ in the month $m$ and $u_{M K T, m}$ denotes the market liquidity innovation. They are the residuals of the following regressions,

$$
\begin{gathered}
L I Q_{i, m}=\alpha_{0}+\alpha_{i} L I Q_{i, m-1}+u_{i, m} \\
L I Q_{M K T, m}=\alpha_{0}+\alpha_{i} L I Q_{M K T, m-1}+u_{M K T, m}
\end{gathered}
$$

where $L I Q_{i, m}$ is the average of a liquidity measure of an individual stock or portfolio $i$ in the month $m$, and $L I Q_{M K T, m}$ is the cross-sectional average of the same liquidity measure of all stocks in the month $m$. The rationale for using liquidity innovations rather than liquidity changes is due to the argument of Acharya and Pedersen (2005) that liquidity is persistent and liquidity changes might induce bias in risk measures.

Table 4 presents the results of the coefficients on liquidity commonality $\left(\beta_{2}\right)$ for financially constrained and unconstrained firms. Following Chordia et al. (2000), we report the coefficients for individual stocks and portfolios under each of the six proxies of financial constraints and four stock liquidity measures. ${ }^{16}$ With only a few exceptions, the coefficients are statistically significant at the $5 \%$ level. In addition, financially constrained firms generally have greater coefficients on liquidity commonality in both magnitude and significance than unconstrained firms have. For instance, the liquidity commonality coefficient, $\beta_{2}$, is $0.366(t$ $=3.86)$ for unconstrained $B A$ firms and $1.407(t=4.82)$ for constrained $B A$ firms based on portfolios, indicating that constrained firms have stronger liquidity commonality than uncon-

\footnotetext{
${ }^{16}$ As the numbers of individual stocks in the financially unconstrained and constrained groups are different, this causes the issues in the calculation of the difference in liquidity commonality between the constrained and unconstrained groups.
} 
strained firms have. Overall, our results suggest that financially constrained firms have higher liquidity risk than unconstrained firms have.

\subsection{Two-way portfolio sorts}

Our prior results raise two questions (1) whether financially constrained firms with higher liquidity risk earn a higher illiquidity premium than unconstrained firms, and (2) whether illiquid firms with more financial constraints produce a higher financial constraint premium than liquid firms. To examine these questions, we use a two-way portfolio sorts approach. At the end of each month of year $t$, we sort all stocks in the sample into terciles and form three portfolios based on their one-month lagged principal component of liquidity measure using NYSE breakpoints. Independently, we sort all stocks into two portfolios based on their proxies of financial constraints for the fiscal year ending in the calendar year $t-1$. Therefore, each stock is assigned to one of six portfolios. We hold the portfolios for the subsequent month and rebalance them monthly.

Table 5 reports the abnormal returns of the FF3 for two-way sorted portfolios. "Liquid" represents a portfolio that comprises firms in the bottom tercile of the principal component of liquidity measure. "Illiquid" represents a portfolio that comprises firms in the top tercile of the principal component of liquidity measure. I-L stands for the illiquidity premium as the difference in returns between illiquid and liquid portfolios. "Unconstrained" denotes a portfolio that contains firms with high $A T$ or $P R$, firms with low $W W$ or $H P$, or firms that have $B R$ or $C R$. "Constrained" denotes a portfolio that contains firms with low $A T$ or $P R$, firms with high $W W$ or $H P$, or firms that have no $B R$ or $C R$. C-U represents the 
financial constraint premium as the difference in returns between financially constrained and unconstrained portfolios.

Holding the principal component of liquidity fixed, financially constrained firms significantly underperform unconstrained firms in liquid portfolios under four out of six proxies of financial constraints (except for the proxies of $A T$ and $W W$ index). However, in illiquid portfolios, financially constrained firms uniformly outperform unconstrained firms, but most of them are statistically insignificant. For example, the financial constraint premium $(\mathrm{C}-\mathrm{U})$ is $-0.538 \%(t=-3.49)$ per month for liquid portfolio and is $0.062 \%(t=0.36)$ per month for illiquid portfolio under $B R$ proxy. The results show a negative relation between financial constraints and stock returns for liquid portfolios and a positive relation for illiquid portfolios, indicating that the mixed relations are conditional on stock liquidity.

Sorting on the principal component of liquidity and holding financial constraints fixed, illiquid firms significantly outperform liquid firms in financially constrained portfolios but insignificantly outperform liquid firms in financially unconstrained portfolios regardless of the proxies of financial constraints. For instance, the illiquidity premium (I-L) is $0.105 \%(t=0.81)$ per month for unconstrained $A T$ portfolio and is $0.826 \%(t=4.40)$ per month for constrained $A T$ portfolio. The results suggest that financially constrained firms earn higher illiquidity premiums than unconstrained firms do.

\subsection{Cross-sectional regressions}

The findings in Table 5 motivate us to examine the pricing of stock liquidity across financially constrained and unconstrained firms as well as an interaction effect between financial 
constraints and stock liquidity. Fama and French (2008) argue that although the portfolio sorts approach provides a clear pattern of returns across different portfolios, it is hard to precisely identify the explanatory variables for average returns. In this subsection, we first explore the pricing of stock liquidity by running Fama-MacBeth (1973) cross-sectional regressions for financially constrained and unconstrained firms, respectively. Next, we investigate the interaction effect between financial constraints and stock liquidity on stock returns. Finally, we examine the interaction effect of the business cycle.

\subsubsection{The impact of stock liquidity on stock returns for financially constrained and unconstrained firms}

Fama and French (2008) point out that regression estimates based on all stocks can be driven by stocks with extreme values of the explanatory variables and extreme returns. To avoid this problem, we split the full sample into the financially constrained and unconstrained subsamples using the same sorting approach as that in Table 2. For each month, we run the following Fama-MacBeth (1973) cross-sectional regressions for the financially constrained and unconstrained subsamples,

$$
R_{i, t+1}-R_{f, t+1}=\gamma_{0}+\gamma_{1} P C L I Q_{i, t}+\gamma_{2} M V_{i, t}+\gamma_{3} B / M_{i, t}+\gamma_{4} M O M_{i, t}+\varepsilon_{i, t+1},
$$

where $R_{i, t+1}$ is the monthly raw returns from July of year $t$ to June of year $t+1, R_{f, t+1}$ is the risk-free rate, $P C L I Q$ is the lagged first principal component of liquidity, $M V$ is the market value of equity at the end of June of year $t, B / M$ is the book value of equity for the fiscal year 
ending in year $t-1$, divided by market value of equity at the end of December in year $t-1$ from the CRSP, and $M O M$ is the cumulative compounded stock returns of the previous six months. We transform each regressor into a standardized variable with a mean of zero and a standard deviation of one. ${ }^{17}$

Table 6 presents the estimates for the subsamples. Regardless of the proxies of financial constraints and the control variables, the coefficients on PCLIQ are uniformly positive at the $1 \%$ significance level for the financially constrained subsamples. For the unconstrained subsamples, the coefficients on PCLIQ are not distinguishable from zero. For instance, including the control variables, the coefficient on PCLIQ is $0.537(t=4.83)$ for the constrained $W W$ subsample and $-0.084(t=-1.09)$ for the unconstrained $W W$ subsample. The results indicate that stock liquidity is strongly priced in the cross-section of stock returns for financially constrained firms, but is not priced at all for unconstrained firms.

\subsubsection{The interaction effect between financial constraints and stock liquidity on stock returns}

Our previous results, as reported in Tables 5 and 6 , suggest that financial constraints and stock liquidity are likely to have an interaction effect on stock returns. We, therefore, investigate this effect by conducting the following Fama-MacBeth (1973) cross-sectional regression for the full sample,

\footnotetext{
${ }^{17}$ We use the standardized variables for Fama-MacBeth (1973) cross-sectional regressions throughout the paper.
} 


$$
\begin{aligned}
R_{i, t+1}-R_{f, t+1} & =\gamma_{0}+\gamma_{1} F C_{i, t}+\gamma_{2} P C L I Q_{i, t}+\gamma_{3} F C \times P C L I Q_{i, t}+\gamma_{4} M V_{i, t} \\
& +\gamma_{5} B / M_{i, t}+\gamma_{6} M_{i, t}+\varepsilon_{i, t+1}
\end{aligned}
$$

where $F C$ is the lagged financial constraints proxy, which is the actual value of $A T, P R$, $W W$, or $H P$, zero for constrained $B R$ or $C R$ firms, or one for unconstrained $B R$ or $C R$ firms. $F C \times P C L I Q$ is an interaction term between financial constraints and the principal component of liquidity.

Table 7 reports the regression estimates under each of the six proxies of financial constraints. In the first regression model, the coefficients on $F C$ do not differ from zero for five out of six proxies except for the $W W$ index, suggesting that financial constraints are not independently priced in the cross-section of stock returns. In the second regression model, the coefficient on PCLIQ is significantly positive, with a coefficient of $0.303(t=3.42)$, indicating that stock liquidity is strongly priced in stock returns. More importantly, the estimates from the third regression model show that the coefficients on $F C \times P C L I Q$ are significant at the $5 \%$ level for five out of six proxies (the only exception is under $A T$ proxy). The results are in line with our hypothesis that there is a strong interaction effect between financial constraints and stock liquidity on stock returns. 


\subsubsection{The interaction effect over the business cycle}

In this section, we extend our investigation from the findings of Table 7 and examine whether the interaction effect between financial constraints and stock liquidity on stock returns varies over the business cycle. Fama and French (1989) find that the term spread and default spread are highly related to short-term and long-term variations in business conditions. These spreads are high during the periods of recessions and low during the periods of economic growth. To capture both effects of term spread and default spread on business conditions, we estimate a total spread as the sum of term spread plus default spread that is the difference between the yields on a ten-year corporate Baa bond and a one-year Treasury bill. ${ }^{18}$ We define a good economic time as a period that has a negative change in the total spread, and define a bad economic time as a period that has a positive change in the total spread. ${ }^{19}$ We split the full sample into the good and bad economic time subsamples.

Table 8 reports the estimates of the cross-sectional regressions for the good and bad economic time subsamples. We use the same independent variables as those in Table 7. Table 8 shows that the coefficients on $F C$ are generally insignificant in both of the good and bad economic time subsamples in the first regression model (except for $B R$ and $C R$ proxies in bad times and $A T$ and the $W W$ index proxies in good times). The results confirm our previous finding in Table 7 that financial constraints are not independently priced either in good or bad economic times. In the second regression model, the coefficient on PCLIQ is signifi-

\footnotetext{
${ }^{18}$ Petkova (2006) measures the term spread as the difference between the yields on a ten-year government bond and a one-year Treasury bill and calculates the default spread as the difference between the yields on a ten-year corporate Baa bond and a ten-year government bond.

${ }^{19}$ We also use the classification of the NBER's business cycle. The estimated results are biased because the NBER's business cycle only contains 69 months of recession months, but contains 399 months of non-recession months.
} 
cantly positive for the good time subsample (with the coefficient of 0.343 and $t=3.18$ ) and marginally significant for the bad time subsample (with the coefficient of 0.255 and $t=1.72$ ). The results imply that stock liquidity is strongly priced in good times. After including the interaction term in the third regression model, the coefficients on $F C \times P C L I Q$ are at the $5 \%$ significance level under the proxies of $P R, B R, W W$, and $H P$ indices and at the $10 \%$ level under $B R$ proxy in the bad time subsample, but they are insignificant in the good time subsample except for the $W W$ index proxy. For instance, the coefficient on $F C \times P C L I Q$ is $-0.476(t=-2.03)$ in the bad time subsample and is $-0.168(t=-0.91)$ in the good time subsample under $P R$ proxy. Overall, our results suggest that stock liquidity is independently priced in good times. In bad times, stock liquidity is generally priced in conjunction with financial constraints.

\section{Conclusion}

This paper investigates the role of stock liquidity in explaining the mixed relations between financial constraints and stock returns and the pricing of stock liquidity between financially constrained and unconstrained firms. We find that financial constraints are negatively related to stock returns for liquid portfolios and positively related to stock returns for illiquidity portfolios. The negative relation is driven by lower returns on constrained-liquid firms, while the positive relation is due to higher returns on constrained-illiquid firms. The possible reasons might be due to investors' different attitudes toward financial constraints for liquid and illiquid firms. Specifically, investors view that financial constraints are less risky for liquid firms, but are riskier in terms of liquidity risk for illiquid firms. Therefore, they require lower 
returns on constrained-liquid firms and demand higher returns on constrained-illiquid firms to compensate for high liquidity risk, leading to the mixed relations between financial constraints and stock returns for liquid and illiquid portfolios.

We also find the strong interaction effect between financial constraints and stock liquidity on stock returns, particularly in bad economic times. Our findings have important implications for policymakers in making capital structure, cash holding, dividend payouts, financing, and investment decisions. During a recession period, the stock prices of financially constrained firms respond significantly to stock liquidity. Moreover, financial constraints are likely to bind more due to tight credit conditions. Raising external capital is costly. Therefore, financially constrained firms could reserve more cash from their cash flows to protect themselves against bad economic conditions and smooth their investment. On the other hand, financially unconstrained firms could follow the market timing theory of Baker and Wurgler (2002) by issuing more debt or repurchasing their own shares. 


\section{References}

Acharya, V. V., Pedersen, L. H., 2005. Asset pricing with liquidity risk. J. Financ. Econ. 77(2), $375-410$.

Admati, A. R., Pfleiderer, P., 1988. A theory of intraday patterns: Volume and price variability. Rev. Financ. Stud. 1(1), 3-40.

Akerlof, G. A., 1970. The market for "Lemons": Quality uncertainty and the market mechanism. Quart. J. Econ. 84(3), 488-500.

Almeida, H., Campello, M., Weisbach, M. S., 2004. The cash flow sensitivity of cash. J. Financ. 59(4), 1777-1804.

Amihud, Y., 2002. Illiquidity and stock returns: Cross-section and time-series effects. J. Financ. Markets 5(1), 31-56.

Amihud, Y., Mendelson. H., 1986. Asset pricing and the bid-ask spread. J. Financ. Econ. 17(2), 223-249.

Baker, M., Wurgler, J., 2002. Market timing and capital structure. J. Financ. 57(1), 1-32.

Banerjee, S., Gatchev, V., Spindt, P., 2007. Stock market liquidity and firm dividend policy. J. Financ. Quant. Anal. 42, 369-398.

Bodnaruk, A., Loughran, T., McDonald, B., 2015. Using 10-k text to gauge financial constraints. J. Financ. Quant. Anal. 50(4), 623-646.

Brennan, M. J., Subrahmanyam, A., 1995. Investment analysis and price formation in securities markets. J. Financ. Econ. 38(3), 361-381.

Brennan, M. J., Subrahmanyam, A., 1996. Market microstructure and asset pricing: On the compensation for illiquidity in stock returns. J. Financ. Econ. 41(3), 441-464.

Butler, A. W., Grullon, G., Weston, J. P., 2005. Stock market liquidity and the cost of issuing equity. J. Financ. Quant. Anal. 40(2), 331-348.

Campello, M., Chen, L., 2010. Are financial constraints priced? Evidence from firm fundamentals and stock returns. J. Money, Credit, Banking 42(6), 1185-1198.

Campello, M., Graham, J. R., Harvey, C. R., 2010. The real effects of financial constraints: Evidence from a financial crisis. J. Financ. Econ. 97(3), 470-487.

Chang, X., Chen, Y., Dasgupta, S., 2019. Macroeconomic conditions, financial constraints, and firms' financing decisions. J. Bank. Finance 101, 242-255.

Chen, S., Wang, Y., 2012. Finance constraints and stock repurchases. J. Financ. Econ. 105(2), 311331.

Chordia, T., Roll, R., Subrahmanyam, A., 2000. Commonality in liquidity. J. Financ. Econ. 56(1), $3-28$.

Dasgupta, S., Li, E. X. N., Yan, D., 2019. Inventory behavior and financial constraints: Theory and evidence. Rev. Financ. Stud. 32(3), 1188-1233. 
Datar, V. T., Naik, N. Y., Radcliffe, R., 1998. Liquidity and asset returns: An alternative test. J. Financ. Markets 1(2), 203-219.

Davis, J. L., Fama, E. F., French, K. R., 2000. Characteristics, covariances, and average returns: 1929 to 1997. J. Financ. 55(1), 389-406.

Denis, D. J., Sibilkov, V., 2010. Financial constraints, investment, and the value of cash holdings. Rev. Financ. Stud. 23(1), 247-269.

Diamond, D. W., Verrecchia, R. E., 1991. Disclosure, liquidity, and the cost of capital. J. Financ. $46(4), 1325-1359$.

Dyreng, S. D., Markle, K.S., 2016. The effect of financial constraints on income shifting by U.S. multinationals. The Account. Rev. 91(6), 1601-1627.

Easley D., O'Hara, M., 1987. Price, trade size, and information in securities markets. J. Financ. Econ. 19(1), 69-90.

Easley, D., Hvidkjær, S., O'Hara, M., 2002. Is information risk a determinant of asset returns? J. Financ. 57(5), 2185-2221.

Easley, D., Kiefer, N. M., O'Hara, M., Paperman, J. B., 1996. Liquidity, information, and infrequently traded stocks. J. Financ. 51(4), 1405-1436.

Edwards, A., Schwab, C., Shevlin, T., 2016. Financial constraints and cash tax savings. The Account. Rev. 91(3), 859-881.

Fama, E. F., French, K. R., 1989. Business conditions and expected returns on stocks and bonds. J. Financ. Econ. 25(1), 23-49.

Fama, E. F., French, K. R., 1993. Common risk factors in the returns on stocks and bonds. J. Financ. Econ. 33(1), 3-56.

Fama, E. F., French, K. R., 2008. Dissecting anomalies. J. Financ. 63(4), 1653-1678.

Fama, E. F., MacBeth, J. D., 1973. Risk, return, and equilibrium: Empirical tests. J. Politic. Econ. $81(3), 607-636$.

Farre-Mensa, J., Ljungqvist. A., 2016. Do measures of financial constraints measure financial constraints? Rev. Financ. Stud. 29(2), 271-308.

Faulkender, M., Wang. R., 2006. Corporate financial policy and the value of cash. J. Financ. 61(4), 1957-1990.

Fazzari, S. M., Hubbard R. G., Petersen. B. C., 1988. Financial constraints and corporate investment. Brook. Pap. on Econ. Activity 1, 141-195.

Gertler, M., Gilchrist, S., 1994. Monetary policy, business cycles, and the behavior of small manufacturing firms. Quart. J. Econ. 109(2), 309-340.

Gilchrist, S., Himmelberg, C. P., 1995. Evidence on the role of cash flow for investment. J. Monetary Econ. 36(3), 541-572.

Glosten, L. R., Harris, L. E., 1988. Estimating the components of the bid/ask spread. J. Financ. Econ. 21(1), 123-142. 
Glosten, L. R., Milgrom, P. R., 1985. Bid, ask, and transaction prices in a specialist market with heterogeneously informed traders. J. Financ. Econ. 14(1), 71-100.

Gomes, J. F., Yaron, A., Zhang, L., 2006. Asset pricing implications of firms' financing constraints. Rev. Financ. Stud. 19(4), 1321-1356.

Gopalan, R., Kadan, O., Pevzner, M., 2012. Asset liquidity and stock liquidity. J. Financ. Quant. Anal. 1(1), 1-70.

Goyenko, R., Holden, C., Trzcinka, C., 2009. Do liquidity measures measure liquidity? J. Financ. Econ. 92(2), 153-181.

Greene, D., 2017. Valuations in corporate takeovers and financial constraints on private targets. J. Financ. Quant. Anal. 52(4), 1343-1373.

Greenwald, B., Stiglitz, J. E., Weiss. A., 1984. Informational imperfections in the capital market and macroeconomic fluctuations. Am. Econ. Rev. 74(2), 194-199.

Hadlock, C. J., Pierce, J. R., 2010. New evidence on measuring financial constraints: Moving beyond the KZ index. Rev. Financ. Stud. 23(5), 1909-1940.

Hahn, J., Lee, H., 2009. Financial constraints, debt capacity, and the cross-section of stock returns. J. Financ. 64(2), 891-921.

Haider, Z. A., Liu, M., Wang, Y., Zhang, Y., 2018. Government ownership, financial constraint, corruption, and corporate performance: International evidence. J. Int. Financ. Markets, Inst. Money 53, 76-93.

Hasbrouck, J., 2009. Trading costs and returns for U.S. equities: Estimating effective costs from daily data. J. Financ. 64(3), 1445-1477.

Hasbrouck, J., Seppi, D. J., 2001. Common factors in prices, order flows, and liquidity. J. Financ. Econ. 59(3), 383-411.

Hennessy, C. A., Whited, T. M., 2007. How costly is external financing? Evidence from a structural estimation. J. Financ. 62(4), 1705-1745.

Hoberg, G., Maksimovic, V., 2015. Redefining financial constraints: A text-based analysis. Rev. Financ. Stud. 28(5), 1312-1352.

Jaffee, D. M., Russell, T., 1976. Imperfect information, uncertainty, and credit rationing. Quart. J. Econ. 90(4), 651-666.

Jin, M., Zhao, S., Kumbhakar, S. C., 2019. Financial constraints and firm productivity: Evidence from Chinese manufacturing. Eur. J. Operation Res. 275, 1139-1156.

Kaplan, S. N., Zingales, L., 1997. Do investment-cash flow sensitivities provide useful measures of financial constraints? Quart. J. Econ. 112(1), 169-215.

Kashyap, A. K., Lamont, O. A., Stein, J. C., 1994. Credit conditions and the cyclical behavior of inventories. Quart. J. Econ. 109(3), 565-592.

Kelly, B., Ljungqvist, A., 2012. Testing asymmetric-information asset pricing models. Rev. Financ. Stud. 25(5), 1366-1413. 
Kiyotaki, N., Moore, J., 1997. Credit cycles. J. Politic. Econ. 105(21), 211-248.

Korajczyk, R., Sadka, R., 2008. Pricing the commonality across alternative measures of liquidity. J. Financ. Econ. 87(1), 45-72.

Kurt, A. C., 2018. How do financial constraints related to financial reporting quality? Evidence from seasoned equity offerings. Eur. Account. Rev. 27(3), 527-557.

Kyle, A. S., 1985. Continuous auctions and insider trading. Econometrica 53(6), 1315-1335.

Lam, F. Y., Wei, K. C., 2011. Limits-to-arbitrage, investment frictions, and the asset growth anomaly. J. Financ. Econ. 102(1), 127-149.

Lamont, O., Polk, C., Saá-Requejo, J., 2001. Financial constraints and stock returns. Rev. Financ. Stud. 14(2), 529-554.

Li, D., 2011. Financial constraints, R\&D investment, and stock returns. Rev. Financ. Stud. 24(9), 2974-3007.

Li, D., Zhang, L., 2010. Does q-theory with investment frictions explain anomalies in the cross-section of returns? J. Financ. Econ. 98(2), 297-314.

Liu, W., 2006. A liquidity-augmented capital asset pricing model. J. Financ. Econ. 82(2), 631-671.

Livdan, D., Sapriza, H., Zhang, L., 2009. Financially constrained stock returns. J. Financ. 64(4), 1827-1862.

Mazouz, K., Daya, W., Yin, S., 2014. Index revisions, systematic liquidity risk and the cost of equity capital. J. Int. Financ. Markets, Inst. Money 33, 283-298.

Morellec, E., Schürhoff, N., 2011. Corporate investment and financing under asymmetric information. J. Financ. Econ. 99(2), 262-288.

Myers, S. C., Majluf, N. S., 1984. Corporate financing and investment decisions when firms have information that investors do not have. J. Financ. Econ. 13(2), 187-221.

Næs, R., Skjeltorp, J. A., Ødegaard, B. A., 2011. Stock market liquidity and the business cycle. J. Financ. 66(1), 139-176.

Newey, W. K. and K. D. West. 1987. A simple, positive semi-definite heteroskedasticity and autocorrelation consistent covariance matrix. Econometrica 55, 703-708.

Odders-White, E. R., Ready, M. J., 2006. Credit ratings and stock liquidity. Rev. Financ. Stud. 19(1), 119-157.

Pastor, L., Stambaugh, R. F., 2003. Liquidity risk and expected stock returns. J. Politic. Econ. 111(3), 642-685.

Petkova, R., 2006. Do the Fama-French factors proxy for innovations in predictive variables? J. Financ. 61(2), 581-612.

Sadka, R., 2006. Momentum and post-earnings-announcement drift anomalies: the role of liquidity risk. J. Financ. Econ. 80(2), 309-349. 
Schauer, C., Elsas, R., Breitkopf, N., 2019. A new measure of financial constraints applicable to private and public firms. J. Bank. Finance 101, 270-295.

Shumway, T., 1997. The delisting bias in CRSP data. J. Financ. 52(1), 327-340.

Stiglitz, J. E., Weiss. A., 1981. Credit rationing and markets with imperfect information. Am. Econ. Rev. 71(3), 393-411.

Whited, T. M., Wu. G., 2006. Financial constraints risk. Rev. Financ. Stud. 19(2), 531-559. 


\section{Appendix A: Firm characteristics}

$B L$ : book leverage, the ratio of the sum of long-term debt (data item DLTT) and debt in current liabilities (data item $D L C$ ) to the book value of equity.

$B / M$ : book-to-market equity, the ratio of the book value of equity to the market value of equity. Following Davis et al. (2000), the book value of equity is calculated as the stockholders' equity (data item $S E Q$ ), plus balance sheet deferred taxes and investment tax credit (data item $T X D I T C$ ) (if available), less book value of preferred stock (in the following order: data item $P S T K R V$ or data item $P S T K L$ or data item PSTK) from the COMPUSTAT database. The $B / M$ ratio of year $t$ is the book value of equity for the fiscal year ending in year $t-1$, divided by market value at the end of December in year $t-1$ from the CRSP.

$C F$ : cash flow, calculated as a ratio of operating income before depreciation (data item $O I B D P$ ) less the sum of interest expenses (data item XINT), income taxes (data item $T X T$ ), dividends of preferred shares (data item $D V P$ ), and dividends of common shares (data item $D V C$ ) to the book value of total assets.

$C H$ : cash holdings, the ratio of cash and short-term investments (data item $C H E$ ) to the book value of total assets.

$M V$ : market capitalization of equity, calculated by the share price at the end of June in year $t$ times the number of shares outstanding from the CRSP. 
$P F$ : profitability, computed as the ratio of the operating income before depreciation (data item $O I B D P$ ) to the book value of total assets.

PR: payout ratio as the total distributions including dividends paid to preferred stocks (data item $D V P$ ), common stocks (data item $D V C$ ), and share repurchases (data item PRSTKC) divided by the operating income before depreciation (data item OIBDP).

$Q$ : Tobin's $Q$, calculated as the ratio of the market value of assets to the book value of total assets. The market value of assets is equal to the book value of total assets (data item $A T$ ) plus the market value of common equity at the end of December in year $t$ from the CRSP less the sum of the book value of common equity (data item $C E Q$ ) and balance sheet deferred taxes (data item $T X D B)$.

$T A$ : tangible asset, defined as the ratio of net property, plant, and equipment (data item PPENT) to the book value of total assets. 


\section{Appendix B: The WW and HP indices}

$W W$ : Whited and Wu's (2006) index is calculated as

$$
\begin{aligned}
W W & =-0.091 C F-0.062 D I V P O S+0.021 T L T D-0.044 L N T A \\
& +0.102 I S G-0.035 S G,
\end{aligned}
$$

where $C F$ is the ratio of income before depreciation (data item $I B+D P$ ) to total assets, $D I V P O S$ is an indicator that takes the value of one if the firm pays cash dividends to preferred stocks or common stocks, TLTD is the ratio of sum of long-term debt and debt in current liabilities to total assets, $L N T A$ is the natural log of total asset, $I S G$ is the firm's three-digit industry sales growth, and $S G$ is the sales (data item $S A L E$ ) growth of a firm.

HP: Hadlock and Pierce's (2010) index is computed as

$$
H P=-0.737 \text { Size }+0.043 \text { Size } e^{2}-0.040 \text { Age, }
$$

where Size is the log of inflation-adjusted book assets, and Age is the number of years that the firm is listed with a non-missing stock price on COMPUSTAT. To calculate this index, Size is winsorized at the log of $\$ 4.5$ billion, and Age is winsorized at 37 years. 
Table 1: Descriptive statistics

This table reports the mean, standard deviation (SD), minimum (Min), median, maximum (Max), and correlation coefficients between the proxies of financial constraints and the stock liquidity measures. We use asset size $(A T)$, payout ratio $(P R)$, bond rating $(B R)$, commercial paper rating $(C R)$, the WW, and HP indices as the proxies for financial constraints. Appendix B provides detailed constructions of the WW and HP indices. We use three individual liquidity measures of the quoted bid-ask spread $(B A, \%)$, price impact $\left(P I, 10^{6}\right)$, and turnover ratio $(T O)$, and a principal component of liquidity measure $(P C L I Q)$ as the first principal component of the quoted bid-ask spread, price impact, and negative turnover ratio. The sample period covers 1985 to 2017 for $B R$ and $C R$ and 1975 to 2017 for the rest.

\begin{tabular}{|c|c|c|c|c|c|c|c|c|c|c|}
\hline & $A T$ & $P R$ & $B R$ & $C R$ & $W W$ & $H P$ & $B A$ & $P I$ & TO & $P C L I Q$ \\
\hline \multicolumn{11}{|c|}{ Descriptive statistics } \\
\hline Mean & 1631 & 0.032 & 0.371 & 0.147 & -0.206 & -3.129 & 5.167 & 6.848 & 0.540 & \\
\hline $\mathrm{SD}$ & 10641 & 31.445 & 0.483 & 0.354 & 1.647 & 0.982 & 8.252 & 59.449 & 0.778 & \\
\hline Min & 0.113 & -8089 & 0.000 & 0.000 & -412.291 & -4.637 & 0.010 & 0.000 & 0.000 & \\
\hline Median & 100 & 0.042 & 0.000 & 0.000 & -0.223 & -3.182 & 2.547 & 0.169 & 0.301 & -0.142 \\
\hline Max & 648349 & 758.100 & 1.000 & 1.000 & 14.961 & 1.348 & 189.824 & 6749.815 & 42.074 & \\
\hline \multicolumn{11}{|c|}{ Spearman's rank correlation } \\
\hline$P R$ & 0.485 & 1.000 & & & & & & & & \\
\hline$B R$ & 0.697 & 0.338 & 1.000 & & & & & & & \\
\hline$C R$ & 0.559 & 0.384 & 0.522 & 1.000 & & & & & & \\
\hline$W W$ & -0.852 & -0.570 & -0.601 & -0.532 & 1.000 & & & & & \\
\hline$H P$ & -0.890 & -0.532 & -0.626 & -0.537 & 0.803 & 1.000 & & & & \\
\hline$B A$ & -0.738 & -0.390 & -0.476 & -0.402 & 0.623 & 0.666 & 1.000 & & & \\
\hline$P I$ & -0.802 & -0.399 & -0.593 & -0.531 & 0.671 & 0.702 & 0.901 & 1.000 & & \\
\hline TO & 0.191 & -0.082 & 0.165 & 0.066 & -0.079 & -0.079 & -0.446 & -0.524 & 1.000 & \\
\hline$P C L I Q$ & -0.497 & -0.152 & -0.335 & -0.216 & 0.374 & 0.401 & 0.812 & 0.802 & -0.795 & 1.000 \\
\hline
\end{tabular}


Table 2: Firm characteristics across the financially constrained and unconstrained groups

This table reports summary statistics of firm characteristics across the financially constrained and unconstrained groups. We use asset size $(A T)$, payout ratio $(P R)$, bond rating $(B R)$, commercial paper rating $(C R)$, the WW, and HP indices as the proxies for financial constraints. At the end of June of each year $t$, we sort stocks into terciles based on their $A T$, $P R, W W$, or $H P$, or sort stocks into two groups based on their $B R$ or $C R$ for the fiscal year ending in the calendar year $t-1$. "U" represents the financially unconstrained group that contains firms in the top tercile of $A T$ or $P R$, firms in the bottom tercile of $W W$ or $H P$, or firms that have $B R$ or $C R$. "C" represents the financially constrained group that contains firms in the bottom tercile of $A T$ or $P R$, firms in the top tercile of $W W$ or $H P$, or firms that have no $B R$ or $C R$. The variables of firm characteristics are the market value $(M V$, in $\$$ millions), book-to-market ratio $(B / M)$, cash flow ratio $(C F)$, cash holdings $(C H)$, book leverage $(B L)$, Tobin's $\mathrm{Q}(Q)$, tangible asset $(T A)$, and profitability $(P F)$. See Appendix A for detailed definitions of firm characteristics. The reported mean is the time-series average of the cross-sectional mean. The sample period covers 1985 to 2017 for $B R$ and $C R$ and 1975 to 2017 for the rest.

\begin{tabular}{|c|c|c|c|c|c|c|c|c|c|c|c|c|c|}
\hline & \multicolumn{12}{|c|}{ Financial Constraints Proxy } \\
\hline & & \multicolumn{2}{|c|}{$A T$} & \multicolumn{2}{|c|}{$P R$} & \multicolumn{2}{|c|}{$B R$} & \multicolumn{2}{|c|}{$C R$} & \multicolumn{2}{|c|}{$W W$} & \multicolumn{2}{|c|}{$H P$} \\
\hline & & $\mathrm{U}$ & $\mathrm{C}$ & $\mathrm{U}$ & $\mathrm{C}$ & $\mathrm{U}$ & $\mathrm{C}$ & $\mathrm{U}$ & $\mathrm{C}$ & $\mathrm{U}$ & $\mathrm{C}$ & $\mathrm{U}$ & $\mathrm{C}$ \\
\hline \multirow[t]{5}{*}{$M V$} & Mean & 5457 & 50 & 5630 & 544 & 6250 & 268 & 13678 & 564 & 5325 & 365 & 5092 & 83 \\
\hline & $\mathrm{SD}$ & 22099 & 132 & 24745 & 5067 & 22564 & 993 & 34172 & 2662 & 22216 & 5176 & 21873 & 715 \\
\hline & Min & 2 & 0 & 0 & 0 & 1 & 0 & 11 & 0 & 0 & 0 & 2 & 0 \\
\hline & Median & 800 & 16 & 277 & 48 & 977 & 56 & 3448 & 86 & 730 & 19 & 628 & 19 \\
\hline & Max & 715600 & 6398 & 715600 & 547363 & 715600 & 51875 & 715600 & 172459 & 715600 & 273268 & 715600 & 104000 \\
\hline \multirow[t]{5}{*}{$B / M$} & Mean & 0.81 & 0.77 & 0.80 & 0.85 & 0.69 & 0.79 & 0.56 & 0.80 & 0.80 & 0.83 & 0.79 & 0.79 \\
\hline & $\mathrm{SD}$ & 1.09 & 0.92 & 0.84 & 1.10 & 1.10 & 0.98 & 1.18 & 1.05 & 1.05 & 1.02 & 0.88 & 1.06 \\
\hline & Min & 0.00 & 0.00 & 0.00 & 0.00 & 0.00 & 0.00 & 0.00 & 0.00 & 0.00 & 0.00 & 0.00 & 0.00 \\
\hline & Median & 0.58 & 0.51 & 0.61 & 0.57 & 0.47 & 0.55 & 0.41 & 0.55 & 0.58 & 0.55 & 0.59 & 0.49 \\
\hline & Max & 41.59 & 19.10 & 35.35 & 41.59 & 41.59 & 28.51 & 35.35 & 41.59 & 35.35 & 25.52 & 35.13 & 34.64 \\
\hline \multirow[t]{5}{*}{$C F$} & Mean & 0.07 & -0.14 & 0.06 & -0.04 & 0.07 & -0.03 & 0.08 & -0.01 & 0.07 & -0.12 & 0.07 & -0.15 \\
\hline & $\mathrm{SD}$ & 0.07 & 0.49 & 0.12 & 0.36 & 0.10 & 0.33 & 0.07 & 0.31 & 0.09 & 0.43 & 0.07 & 0.50 \\
\hline & Min & -2.73 & -24.00 & -9.65 & -24.00 & -3.65 & -10.12 & -2.68 & -11.12 & -2.79 & -24.00 & -2.73 & -24.00 \\
\hline & Median & 0.08 & 0.02 & 0.06 & 0.06 & 0.08 & 0.06 & 0.08 & 0.06 & 0.08 & 0.02 & 0.08 & 0.01 \\
\hline & Max & 0.54 & 1.71 & 0.70 & 1.71 & 0.76 & 1.69 & 0.67 & 1.69 & 1.69 & 0.95 & 0.67 & 1.71 \\
\hline \multirow[t]{5}{*}{$\mathrm{CH}$} & Mean & 0.10 & 0.25 & 0.15 & 0.19 & 0.11 & 0.19 & 0.08 & 0.17 & 0.10 & 0.23 & 0.11 & 0.26 \\
\hline & SD & 0.13 & 0.27 & 0.16 & 0.23 & 0.14 & 0.23 & 0.09 & 0.21 & 0.13 & 0.26 & 0.13 & 0.27 \\
\hline & Min & -0.00 & -0.01 & -0.00 & -0.01 & 0.00 & -0.00 & 0.00 & -0.01 & -0.00 & -0.01 & -0.00 & -0.01 \\
\hline & Median & 0.06 & 0.14 & 0.09 & 0.09 & 0.05 & 0.09 & 0.05 & 0.08 & 0.06 & 0.12 & 0.06 & 0.15 \\
\hline & Max & 0.99 & 1.00 & 0.99 & 1.00 & 0.97 & 1.00 & 0.88 & 0.99 & 0.98 & 1.00 & 0.97 & 1.00 \\
\hline \multirow[t]{5}{*}{$B L$} & Mean & 1.00 & 0.57 & 0.49 & 0.93 & 0.99 & 0.59 & 0.96 & 0.68 & 0.77 & 0.59 & 1.04 & 0.51 \\
\hline & $\mathrm{SD}$ & 48.64 & 14.74 & 6.73 & 41.31 & 44.48 & 12.15 & 17.34 & 29.05 & 17.70 & 17.10 & 53.73 & 16.62 \\
\hline & Min & -1074.19 & -1154.83 & -580.76 & -1473.10 & -2618.35 & -1154.83 & -466.33 & -2618.35 & -633.84 & -1473.10 & -2618.35 & -1473.10 \\
\hline & Median & 0.51 & 0.15 & 0.29 & 0.32 & 0.60 & 0.29 & 0.57 & 0.34 & 0.47 & 0.21 & 0.46 & 0.16 \\
\hline & Max & 7329.29 & 1149.33 & 232.04 & 7329.29 & 3096.64 & 753.73 & 960.50 & 3096.64 & 2183.59 & 1149.33 & 7329.29 & 837.96 \\
\hline \multirow[t]{5}{*}{$Q$} & Mean & 1.55 & 2.80 & 1.65 & 2.19 & 1.68 & 2.10 & 1.77 & 2.01 & 1.56 & 2.47 & 1.53 & 2.84 \\
\hline & $\mathrm{SD}$ & 1.11 & 4.22 & 1.17 & 3.19 & 1.09 & 2.51 & 1.05 & 2.41 & 1.15 & 3.32 & 1.02 & 4.19 \\
\hline & Min & 0.18 & 0.12 & 0.21 & 0.12 & 0.26 & 0.21 & 0.26 & 0.12 & 0.18 & 0.12 & 0.26 & 0.12 \\
\hline & Median & 1.26 & 1.56 & 1.30 & 1.35 & 1.39 & 1.41 & 1.49 & 1.38 & 1.26 & 1.48 & 1.25 & 1.62 \\
\hline & Max & 44.16 & 142.82 & 23.21 & 142.82 & 22.48 & 76.58 & 15.75 & 99.23 & 30.34 & 142.82 & 23.28 & 142.82 \\
\hline \multirow[t]{5}{*}{$T A$} & Mean & 0.31 & 0.20 & 0.27 & 0.23 & 0.29 & 0.24 & 0.31 & 0.25 & 0.31 & 0.21 & 0.30 & 0.20 \\
\hline & $\mathrm{SD}$ & 0.17 & 0.16 & 0.16 & 0.17 & 0.16 & 0.16 & 0.16 & 0.16 & 0.17 & 0.16 & 0.16 & 0.17 \\
\hline & Min & 0.00 & 0.00 & 0.00 & 0.00 & 0.00 & 0.00 & 0.02 & 0.00 & 0.00 & 0.00 & 0.00 & 0.00 \\
\hline & Median & 0.28 & 0.16 & 0.25 & 0.20 & 0.26 & 0.22 & 0.28 & 0.22 & 0.29 & 0.17 & 0.27 & 0.16 \\
\hline & Max & 0.92 & 1.00 & 0.90 & 1.00 & 0.88 & 0.99 & 0.84 & 0.99 & 0.93 & 1.00 & 0.93 & 1.00 \\
\hline \multirow[t]{5}{*}{$P F$} & Mean & 0.15 & -0.10 & 0.15 & 0.00 & 0.14 & 0.01 & 0.16 & 0.03 & 0.15 & -0.08 & 0.15 & -0.11 \\
\hline & $\mathrm{SD}$ & 0.08 & 0.50 & 0.10 & 0.37 & 0.11 & 0.35 & 0.08 & 0.33 & 0.10 & 0.43 & 0.08 & 0.50 \\
\hline & Min & -0.92 & -18.87 & 0.00 & -18.87 & -3.08 & -18.28 & -2.65 & -18.28 & -2.51 & -18.87 & -0.64 & -18.87 \\
\hline & Median & 0.15 & 0.04 & 0.14 & 0.10 & 0.14 & 0.10 & 0.16 & 0.11 & 0.15 & 0.04 & 0.15 & 0.04 \\
\hline & Max & 1.93 & 3.25 & 3.25 & 1.71 & 1.39 & 1.70 & 0.97 & 1.70 & 1.93 & 1.25 & 0.97 & 3.25 \\
\hline
\end{tabular}


Table 3: The return, stock liquidity, and liquidity risk across the financially constrained and unconstrained groups

This table reports the monthly return performance in Panel A, the stock liquidity measures in Panel B and the liquidity risk measures in Panel C across the financially constrained and unconstrained groups. We use asset size $(A T)$, payout ratio $(P R)$, bond rating $(B R)$, commercial paper rating $(C R)$, the WW, and HP indices as the proxies for financial constraints. At the end of June of each year $t$, we sort stocks into terciles based on their $A T$, $P R$, $W W$, or $H P$, or sort stocks into two groups based on their $B R$ or $C R$ for the fiscal year ending in the calendar year $t-1$. "U" represents the financially unconstrained group that contains firms in the top tercile of $A T$ or $P R$, firms in the bottom tercile of $W W$ or $H P$, or firms that have $B R$ or $C R$. "C" represents the financially constrained group that contains firms in the bottom tercile of $A T$ or $P R$, firms in the top tercile of $W W$ or $H P$, or firms that have no $B R$ or $C R$. "C-U" represents the difference in the estimated variables between the constrained and unconstrained groups. The excess return is the return that exceeds the risk-free rate. The FF3 alpha is the intercept of the Fama and French (1993) three-factor model, which represents the abnormal return after adjusting for the Fama and French (1993) three factors. We report three individual liquidity measures of the quoted bid-ask spread $(B A, \%)$, price impact $\left(P I, 10^{6}\right)$, and turnover ratio $(T O)$, and a principal component of liquidity measure $(P C L I Q)$ as the first principal component of the quoted bid-ask spread, price impact, and negative turnover ratio. $\beta_{\text {Sadka }}$ and $\beta_{A P}$ are the liquidity risk measures of Sadka (2006) and Acharya and Pedersen (2005), respectively. The sample period covers 1985 to 2017 for $B R$ and $C R$ and 1975 to 2017 for the rest.

\begin{tabular}{|c|c|c|c|c|c|c|c|c|c|c|c|c|c|c|c|c|c|c|}
\hline & \multicolumn{18}{|c|}{ Financial Constraints Proxy } \\
\hline & \multicolumn{3}{|c|}{$A T$} & \multicolumn{3}{|c|}{$P R$} & \multicolumn{3}{|c|}{$B R$} & \multicolumn{3}{|c|}{$C R$} & \multicolumn{3}{|c|}{$W W$} & \multicolumn{3}{|c|}{$H P$} \\
\hline & $\mathrm{U}$ & $\mathrm{C}$ & $\mathrm{C}-\mathrm{U}$ & $\mathrm{U}$ & $\mathrm{C}$ & $\mathrm{C}-\mathrm{U}$ & $\mathrm{U}$ & $\mathrm{C}$ & $\mathrm{C}-\mathrm{U}$ & $\mathrm{U}$ & $\mathrm{C}$ & $\mathrm{C}-\mathrm{U}$ & $\mathrm{U}$ & $\mathrm{C}$ & $\mathrm{C}-\mathrm{U}$ & $\mathrm{U}$ & $\mathrm{C}$ & $\mathrm{C}-\mathrm{U}$ \\
\hline \multicolumn{19}{|c|}{ Panel A: Stock returns } \\
\hline Excess Return (\%) & 0.90 & 1.11 & 0.21 & 0.95 & 1.01 & 0.06 & 1.09 & 0.88 & -0.21 & 1.03 & 0.94 & -0.09 & 0.86 & 1.26 & 0.41 & 0.95 & 0.97 & 0.02 \\
\hline & $(3.38)$ & $(3.03)$ & $(0.92)$ & $(4.10)$ & $(2.96)$ & $(0.36)$ & $(3.35)$ & $(2.39)$ & $(-1.29)$ & $(3.77)$ & $(2.55)$ & $(-0.41)$ & $(3.32)$ & $(3.41)$ & $(1.70)$ & $(3.69)$ & $(2.57)$ & $(0.08)$ \\
\hline FF3 alpha (\%) & -0.02 & 0.28 & 0.30 & 0.16 & 0.06 & -0.10 & 0.18 & 0.11 & -0.07 & 0.20 & 0.11 & -0.09 & -0.05 & 0.39 & 0.45 & 0.04 & 0.11 & 0.07 \\
\hline & $(-0.25)$ & $(1.62)$ & $(1.67)$ & $(2.38)$ & $(0.49)$ & $(-1.03)$ & $(1.86)$ & $(0.81)$ & $(-0.51)$ & $(2.04)$ & $(0.93)$ & $(-0.63)$ & $(-0.74)$ & $(2.39)$ & $(2.53)$ & $(0.58)$ & $(0.64)$ & $(0.40)$ \\
\hline \multicolumn{19}{|c|}{ Panel B: Stock illiquidity } \\
\hline$B A$ & 1.57 & 8.65 & 7.09 & 3.18 & 6.26 & 3.08 & 1.87 & 4.68 & 2.81 & 0.91 & 4.23 & 3.32 & 1.73 & 8.12 & 6.38 & 1.84 & 8.43 & 6.59 \\
\hline & $(6.39)$ & $(7.36)$ & $(7.45)$ & $(6.57)$ & $(6.90)$ & $(7.14)$ & $(4.62)$ & $(5.44)$ & $(6.04)$ & $(5.14)$ & $(5.27)$ & $(5.19)$ & $(6.34)$ & $(7.16)$ & $(7.17)$ & $(6.73)$ & $(7.13)$ & $(7.11)$ \\
\hline \multirow[t]{2}{*}{$P I$} & 0.23 & 17.67 & 17.44 & 2.87 & 9.13 & 6.26 & 0.81 & 8.44 & 7.63 & 0.02 & 7.05 & 7.03 & 0.31 & 16.66 & 16.35 & 0.47 & 16.50 & 16.04 \\
\hline & $(3.37)$ & $(6.27)$ & $(6.29)$ & $(3.50)$ & $(6.10)$ & $(5.55)$ & $(3.80)$ & $(5.52)$ & $(5.66)$ & $(2.59)$ & $(5.67)$ & $(5.66)$ & $(4.42)$ & $(5.99)$ & $(5.99)$ & $(4.14)$ & $(6.31)$ & $(6.35)$ \\
\hline \multirow[t]{2}{*}{$T O$} & 0.60 & 0.43 & -0.17 & 0.46 & 0.55 & 0.09 & 0.70 & 0.58 & -0.12 & 0.60 & 0.62 & 0.02 & 0.54 & 0.47 & -0.07 & 0.52 & 0.48 & -0.04 \\
\hline & $(7.05)$ & $(8.00)$ & $(-2.92)$ & $(6.87)$ & $(8.53)$ & $(3.77)$ & $(8.77)$ & $(10.22)$ & $(-2.84)$ & $(7.64)$ & $(10.39)$ & $(0.59)$ & $(6.82)$ & $(8.01)$ & $(-1.44)$ & $(7.11)$ & $(7.93)$ & $(-0.92)$ \\
\hline \multirow[t]{2}{*}{$P C L I Q$} & -0.36 & 0.47 & 0.83 & -0.14 & 0.13 & 0.27 & -0.38 & 0.07 & 0.45 & -0.43 & -0.03 & 0.41 & -0.31 & 0.40 & 0.71 & -0.29 & 0.41 & 0.70 \\
\hline & $(-5.44)$ & $(3.81)$ & $(8.98)$ & $(-2.03)$ & $(1.28)$ & $(5.94)$ & $(-4.90)$ & $(0.61)$ & $(9.42)$ & $(-7.91)$ & $(-0.26)$ & $(6.02)$ & $(-4.68)$ & $(3.26)$ & $(8.36)$ & $(-4.61)$ & $(3.21)$ & $(7.66)$ \\
\hline \multicolumn{19}{|c|}{ Panel C: Liquidity beta } \\
\hline \multirow[t]{2}{*}{$\beta_{\text {Sadka }}$} & 2.02 & 5.03 & 3.01 & 2.31 & 4.14 & 1.83 & 2.11 & 4.06 & 1.94 & 0.78 & 3.82 & 3.04 & 2.00 & 4.87 & 2.87 & 2.14 & 4.80 & 2.67 \\
\hline & $(2.19)$ & $(2.73)$ & $(1.93)$ & $(2.90)$ & $(2.81)$ & $(1.89)$ & $(2.13)$ & $(2.90)$ & (1.99) & $(0.90)$ & $(2.83)$ & $(2.30)$ & $(2.27)$ & $(2.75)$ & $(1.91)$ & $(2.45)$ & $(2.57)$ & $(1.63)$ \\
\hline \multirow[t]{2}{*}{$\beta_{A P}$} & 0.37 & 3.04 & 2.67 & 0.74 & 1.75 & 1.01 & 0.60 & 1.56 & 0.97 & -0.08 & 1.37 & 1.45 & 0.26 & 2.58 & 2.32 & 0.37 & 2.98 & 2.61 \\
\hline & $(0.33)$ & $(0.59)$ & $(0.64)$ & $(0.33)$ & $(0.43)$ & $(0.53)$ & $(0.33)$ & $(0.43)$ & $(0.50)$ & $(-0.10)$ & $(0.40)$ & $(0.52)$ & $(0.21)$ & $(0.51)$ & $(0.58)$ & $(0.30)$ & $(0.56)$ & $(0.62)$ \\
\hline
\end{tabular}


Table 4: Commonality in liquidity for the financially constrained and unconstrained groups

This table reports the liquidity commonality of individual stocks and portfolios for the financially constrained and unconstrained groups. We estimate the liquidity commonality $\left(\beta_{2}\right)$ using the following equation,

$$
u_{i, m}=b_{0}+\beta_{2} u_{M K T, m}+e_{i, m},
$$

where $u_{i, m}$ denotes the liquidity innovation of individual stock or portfolio $i$ and $u_{M K T, m}$ denotes the market liquidity innovation. They are the residual of the following regressions,

$$
\begin{gathered}
L I Q_{i, m}=\alpha_{0}+\alpha_{i} L I Q_{i, m-1}+u_{i, m} \\
L I Q_{M K T, m}=\alpha_{0}+\alpha_{i} L I Q_{M K T, m-1}+u_{M K T, m},
\end{gathered}
$$

where $L I Q_{i, m}$ is the stock liquidity measure of an individual stock or a portfolio in the financially unconstrained or constrained groups in month $m$, and $L I Q_{M K T, m}$ is the corresponding average liquidity measure of all stocks in month $m$. We estimate three individual liquidity measures, including the quoted bid-ask spread $(B A, \%)$, price impact $(P I$, $\left.10^{6}\right)$, and turnover ratio $(T O)$, and a principal component of liquidity measure $(P C L I Q)$. We use asset size $(A T)$, payout ratio $(P R)$, bond rating $(B R)$, commercial paper rating $(C R)$, the $\mathrm{WW}$, and $\mathrm{HP}$ indices as the proxies for financial constraints. At the end of June of each year $t$, we sort stocks into terciles based on their $A T, P R$, $W W$, or $H P$, or sort stocks into two groups based on their $B R$ or $C R$ for the fiscal year ending in the calendar year $t-1$. "Unconstrained" represents the financially unconstrained group that contains firms in the top tercile of $A T$ or $P R$, firms in the bottom tercile of $W W$ or $H P$, or firms that have $B R$ or $C R$. "Constrained" represents the financially constrained group that contains firms in the bottom tercile of $A T$ or $P R$, firms in the top tercile of $W W$ or $H P$, or firms that have no $B R$ or $C R$. "C-U" represents the difference between the constrained and unconstrained groups. The sample period covers 1985 to 2017 for $B R$ and $C R$ and 1975 to 2017 for the rest.

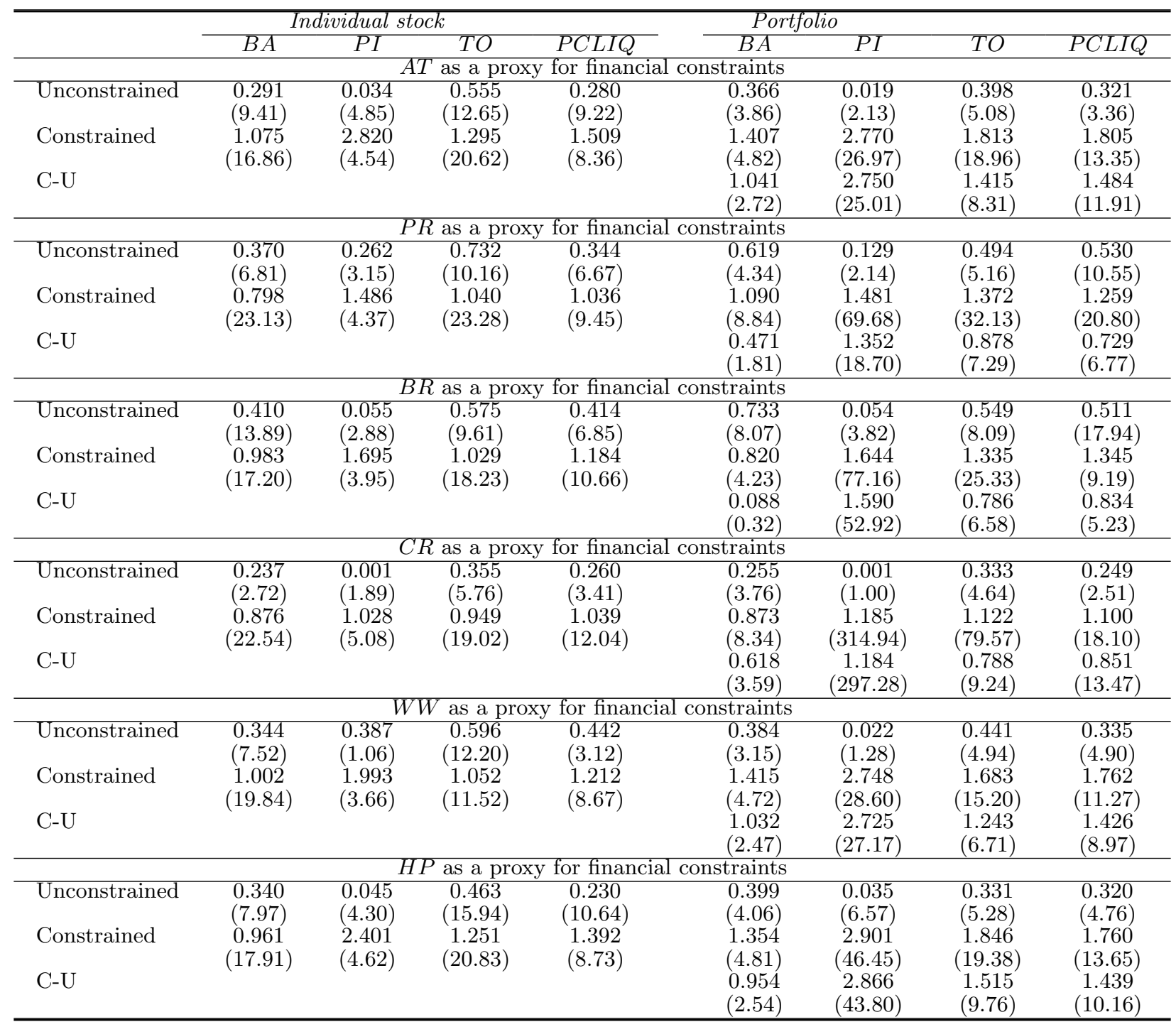




\section{Table 5: The abnormal returns of portfolios sorted on stock liquidity and financial constraints}

This table reports the abnormal returns after adjusting for the Fama and French (1993) three factors for two-way sorted portfolios based on the principal component of liquidity and financial constraints. At the end of each month of year $t$, we sort stocks into three portfolios based on their one-month lagged principal component of liquidity measure using NYSE breakpoints and independently sort stocks into two portfolios based on their proxies of financial constraints for the fiscal year ending in the calendar year $t-1$. We hold the portfolios for the subsequent month and rebalance them monthly. The principal component of liquidity measure is estimated from three individual liquidity measures of the quoted bid-ask spread, price impact, and negative turnover ratio. "Liquid" represents a portfolio that comprises firms in the bottom tercile of the principal component of liquidity measure. "Illiquid" represents a portfolio that comprises firms in the top tercile of the principal component of liquidity measure. "I-L" stands for the difference in returns between the illiquid and liquid portfolios. We use asset size $(A T)$, payout ratio $(P R)$, bond rating $(B R)$, commercial paper rating $(C R)$, the WW, and HP indices as the proxies for financial constraints. "Unconstrained" represents a financially unconstrained portfolio that contains firms with high $A T$ or $P R$, firms with low $W W$ or $H P$, or firms that have $B R$ or $C R$. "Constrained" represents a financially constrained portfolio that contains firms with low $A T$ or $P R$, firms with high $W W$ or $H P$, or firms that have no $B R$ or $C R$. "C-U" represents the difference in returns between the constrained and unconstrained portfolios. The corresponding $t$-statistics based on Newey and West's (1987) standard errors are in parentheses. The sample period covers 1985 to 2017 for $B R$ and $C R$ and 1975 to 2017 for the rest.

\begin{tabular}{|c|c|c|c|c|c|c|}
\hline & Unconstrained & Constrained & $\mathrm{C}-\mathrm{U}$ & Unconstrained & Constrained & $\mathrm{C}-\mathrm{U}$ \\
\hline & \multicolumn{3}{|c|}{$A T$ as a proxy for financial constraints } & \multicolumn{3}{|c|}{$P R$ as a proxy for financial constraints } \\
\hline \multirow[t]{2}{*}{ Liquid } & -0.039 & -0.223 & -0.184 & 0.086 & -0.299 & -0.384 \\
\hline & $(-0.39)$ & $(-1.46)$ & $(-1.26)$ & $(0.99)$ & $(-2.51)$ & $(-3.28)$ \\
\hline \multirow[t]{2}{*}{ Illiquid } & 0.066 & 0.603 & 0.536 & 0.271 & 0.309 & 0.038 \\
\hline & $(0.64)$ & $(3.12)$ & $(3.02)$ & $(2.91)$ & $(2.07)$ & $(0.33)$ \\
\hline \multirow[t]{3}{*}{ I-L } & 0.105 & 0.826 & & 0.185 & 0.607 & \\
\hline & $(0.81)$ & $(4.40)$ & & $(1.83)$ & $(3.78)$ & \\
\hline & \multicolumn{3}{|c|}{$B R$ as a proxy for financial constraints } & \multicolumn{3}{|c|}{$C R$ as a proxy for financial constraints } \\
\hline \multirow[t]{2}{*}{ Liquid } & 0.177 & -0.361 & -0.538 & 0.209 & -0.255 & -0.464 \\
\hline & $(1.33)$ & $(-2.49)$ & $(-3.49)$ & $(1.30)$ & $(-1.93)$ & $(-2.53)$ \\
\hline \multirow[t]{2}{*}{ Illiquid } & 0.399 & 0.461 & 0.062 & 0.238 & 0.436 & 0.199 \\
\hline & $(2.84)$ & $(2.57)$ & $(0.36)$ & $(1.26)$ & $(2.64)$ & $(0.86)$ \\
\hline \multirow[t]{3}{*}{ I-L } & 0.222 & 0.822 & & 0.028 & 0.691 & \\
\hline & $(1.41)$ & $(4.31)$ & & $(0.13)$ & $(4.11)$ & \\
\hline & \multicolumn{3}{|c|}{$W W$ as a proxy for financial constraints } & \multicolumn{3}{|c|}{$H P$ as a proxy for financial constraints } \\
\hline \multirow[t]{2}{*}{ Liquid } & -0.088 & -0.166 & -0.078 & 0.016 & -0.410 & -0.426 \\
\hline & $(-0.87)$ & $(-1.16)$ & $(-0.54)$ & $(0.17)$ & $(-2.52)$ & $(-2.97)$ \\
\hline \multirow[t]{2}{*}{ Illiquid } & 0.106 & 0.526 & 0.420 & 0.236 & 0.457 & 0.221 \\
\hline & (1.14) & $(2.89)$ & $(2.50)$ & $(2.35)$ & $(2.39)$ & (1.33) \\
\hline \multirow[t]{2}{*}{ I-L } & 0.193 & 0.691 & & 0.220 & 0.867 & \\
\hline & $(1.58)$ & $(3.61)$ & & $(1.76)$ & $(4.32)$ & \\
\hline
\end{tabular}


Table 6: Fama-MacBeth cross-sectional regressions for the financially constrained and unconstrained groups

For each month, we estimate Fama and MacBeth cross-sectional regression of monthly excess returns on the lagged principal component of liquidity $(P C L I Q)$ and the control variables of the market value of equity ( $M V)$, book-tomarket ratio $(B / M)$, and momentum $(M O M)$ for the financially constrained and unconstrained subsamples. $P C L I Q$ is the first principal component of three individual liquidity measures of the quoted bid-ask spread, price impact, and negative turnover ratio, $M V$ is the market value of equity at the end of June of year $t, B / M$ is the ratio of the book value of equity for the fiscal year ending in year $t-1$, divided by the market value of equity at the end of June in year $t-1$ from the CRSP, and MOM is the cumulative compounded stock returns of the previous six months. We use asset size $(A T)$, payout ratio $(P R)$, bond rating $(B R)$, commercial paper rating $(C R)$, the WW, and HP indices as the proxies for financial constraints. At the end of June of each year $t$, we sort stocks into terciles on their $A T, P R$, $W W$, and $H P$, or sort stocks into two groups based on their $B R$ and $C R$ for the fiscal year ending in the calendar year $t-1$ and produce the financially constrained and unconstrained subsamples. "Unconstrained" represents the financially unconstrained subsample that contains firms in the top tercile of $A T$ or $P R$, firms in the bottom tercile of $W W$ or $H P$, or firms that have $B R$ or $C R$. "Constrained" represents the financially constrained subsample that contains firms in the bottom tercile of $A T$ or $P R$, firms in the top tercile of $W W$ or $H P$, or firms that have no $B R$ and $C R$. We winsorize each regressor at the top and bottom $1 \%$ and transform them to have a mean of zero and a standard deviation of one. The corresponding $t$-statistics based on Newey and West's (1987) standard errors are in parentheses. The sample period covers 1985 to 2017 for $B R$ and $C R$ and 1975 to 2017 for the rest.

\begin{tabular}{|c|c|c|c|c|c|c|c|c|c|c|}
\hline & Constant & $P C L I Q$ & $M V$ & $B / M$ & $M O M$ & Constant & $P C L I Q$ & $M V$ & $B / M$ & $M O M$ \\
\hline & \multicolumn{5}{|c|}{$A T$ as a proxy for financial constraints } & \multicolumn{5}{|c|}{$P R$ as a proxy for financial constraints } \\
\hline \multirow[t]{4}{*}{ Unconstrained } & 0.443 & 0.083 & & & & 0.752 & 0.147 & & & \\
\hline & $(0.90)$ & $(0.87)$ & & & & $(2.35)$ & $(1.85)$ & & & \\
\hline & -0.022 & 0.033 & -0.476 & 0.064 & 0.057 & 0.141 & 0.081 & -0.276 & 0.064 & 0.127 \\
\hline & $(-0.04)$ & $(0.36)$ & $(-1.63)$ & $(0.95)$ & $(1.04)$ & $(0.32)$ & $(1.02)$ & $(-0.68)$ & $(1.01)$ & $(2.14)$ \\
\hline \multirow[t]{5}{*}{ Constrained } & 0.532 & 0.638 & & & & 0.537 & 0.436 & & & \\
\hline & $(1.34)$ & $(5.58)$ & & & & $(1.44)$ & $(4.30)$ & & & \\
\hline & -0.198 & 0.533 & 0.090 & 0.405 & 0.039 & 0.045 & 0.377 & -0.052 & 0.256 & 0.069 \\
\hline & $(-0.39)$ & $(4.74)$ & $(1.10)$ & $(4.41)$ & $(0.52)$ & $(0.10)$ & $(3.81)$ & $(-0.41)$ & $(3.88)$ & $(1.15)$ \\
\hline & \multicolumn{5}{|c|}{$B R$ as a proxy for financial constraints } & \multicolumn{5}{|c|}{$C R$ as a proxy for financial constraints } \\
\hline \multirow[t]{4}{*}{ Unconstrained } & 1.119 & 0.073 & & & & 1.769 & -0.104 & & & \\
\hline & $(2.37)$ & $(0.69)$ & & & & $(3.00)$ & $(-1.08)$ & & & \\
\hline & 0.359 & 0.072 & 0.008 & 0.111 & 0.120 & 0.308 & -0.035 & -0.315 & 0.038 & 0.173 \\
\hline & $(0.66)$ & $(0.73)$ & $(0.06)$ & $(1.30)$ & (1.64) & $(0.45)$ & $(-0.35)$ & $(-1.63)$ & $(0.50)$ & $(2.29)$ \\
\hline \multirow[t]{5}{*}{ Constrained } & 0.335 & 0.486 & & & & 0.499 & 0.401 & & & \\
\hline & $(0.79)$ & $(4.69)$ & & & & $(1.17)$ & $(4.10)$ & & & \\
\hline & -0.077 & 0.406 & 0.042 & 0.245 & 0.069 & 0.103 & 0.340 & 0.057 & 0.233 & 0.073 \\
\hline & $(-0.14)$ & $(4.07)$ & $(0.69)$ & $(3.17)$ & $(1.00)$ & $(0.20)$ & $(3.58)$ & (1.03) & $(3.18)$ & (1.11) \\
\hline & \multicolumn{5}{|c|}{$W W$ as a proxy for financial constraints } & \multicolumn{5}{|c|}{$H P$ as a proxy for financial constraints } \\
\hline \multirow[t]{4}{*}{ Unconstrained } & 0.694 & -0.053 & & & & 0.776 & 0.049 & & & \\
\hline & $(1.57)$ & $(-0.68)$ & & & & $(1.84)$ & $(0.59)$ & & & \\
\hline & 0.246 & -0.084 & -0.443 & 0.070 & 0.045 & 0.152 & -0.015 & -0.571 & 0.112 & 0.067 \\
\hline & $(0.48)$ & $(-1.09)$ & $(-1.46)$ & $(1.26)$ & $(0.87)$ & $(0.34)$ & $(-0.19)$ & $(-1.84)$ & $(1.85)$ & $(1.40)$ \\
\hline \multirow[t]{4}{*}{ Constrained } & 0.680 & 0.595 & & & & 0.474 & 0.605 & & & \\
\hline & $(1.74)$ & $(5.32)$ & & & & $(1.14)$ & $(5.22)$ & & & \\
\hline & 0.129 & 0.537 & 0.480 & 0.333 & 0.011 & -0.268 & 0.541 & 0.123 & 0.357 & 0.068 \\
\hline & $(0.26)$ & $(4.83)$ & $(2.36)$ & $(3.75)$ & $(0.15)$ & $(-0.50)$ & $(4.83)$ & (1.47) & $(3.80)$ & $(0.90)$ \\
\hline
\end{tabular}


Table 7: Fama-MacBeth cross-sectional regressions with the interaction term

For each month, we estimate Fama and MacBeth cross-sectional regressions of monthly excess returns on the proxies of financial constraints $(F C)$, principal component of liquidity $(P C L I Q)$, the interaction term $(F C \times P C L I Q)$, and the control variables of market value of equity $(M V)$, book-to-market $(B / M)$, and momentum $(M O M)$. We use asset size $(A T)$, payout ratio $(P R)$, bond rating $(B R)$, commercial paper rating $(C R)$, the WW, and HP indices as the proxies for financial constraints. $F C$ is the actual value of $A T, P R, W W$, or $H P$, one for firms with $B R$ or $C R$, or zero for firms without $B R$ or $C R, P C L I Q$ is the first principal component of three individual liquidity measures of the quoted bid-ask spread, price impact, and negative turnover ratio, $M V$ is the market value of equity at the end of June of year $t, B / M$ is the ratio of the book value of equity for the fiscal year ending in year $t-1$, divided by the market value of equity at the end of June in year $t-1$ from the CRSP, and $M O M$ is the cumulative compounded stock returns of the previous six months. We winsorize each regressor at the top and bottom $1 \%$ and transform them to have a mean of zero and a standard deviation of one. The corresponding $t$-statistics based on Newey and West's (1987) standard errors are in parentheses. The sample period covers 1985 to 2017 for $B R$ and $C R$ and 1975 to 2017 for the rest.

\begin{tabular}{|c|c|c|c|c|c|c|}
\hline Constant & $F C$ & $P C L I Q$ & $F C \times P C L I Q$ & 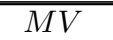 & $\bar{B} / M$ & $M O M$ \\
\hline \multicolumn{7}{|c|}{$A T$ as a proxy for financial constraints } \\
\hline 0.311 & -0.102 & & & 0.040 & 0.337 & 0.059 \\
\hline$(0.82)$ & $(-1.83)$ & & & $(0.78)$ & $(5.91)$ & $(1.04)$ \\
\hline-0.007 & & 0.303 & & -0.150 & 0.200 & 0.076 \\
\hline$(-0.02)$ & & $(3.42)$ & & $(-0.94)$ & $(3.66)$ & $(1.39)$ \\
\hline-0.534 & -0.560 & 0.336 & -0.237 & -0.195 & 0.202 & 0.078 \\
\hline$(-0.50)$ & $(-0.67)$ & $(1.78)$ & $(-0.93)$ & $(-1.07)$ & $(3.68)$ & $(1.45)$ \\
\hline \multicolumn{7}{|c|}{$P R$ as a proxy for financial constraints } \\
\hline 0.396 & -0.005 & & & -0.047 & 0.332 & 0.070 \\
\hline$(0.87)$ & $(-0.12)$ & & & $(-1.24)$ & $(6.07)$ & $(1.26)$ \\
\hline-0.007 & & 0.303 & & -0.150 & 0.200 & 0.076 \\
\hline$(-0.02)$ & & $(3.42)$ & & $(-0.94)$ & $(3.66)$ & $(1.39)$ \\
\hline-0.910 & 0.156 & 0.565 & -0.301 & -0.139 & 0.212 & 0.090 \\
\hline$(-0.99)$ & $(1.97)$ & $(3.53)$ & $(-2.09)$ & $(-0.93)$ & $(3.96)$ & $(1.69)$ \\
\hline \multicolumn{7}{|c|}{$B R$ as a proxy for financial constraints } \\
\hline 0.287 & 0.096 & & & -0.043 & 0.271 & 0.048 \\
\hline$(0.60)$ & $(1.28)$ & & & $(-1.08)$ & $(4.07)$ & $(0.68)$ \\
\hline-0.007 & & 0.303 & & -0.150 & 0.200 & 0.076 \\
\hline$(-0.02)$ & & $(3.42)$ & & $(-0.94)$ & $(3.66)$ & $(1.39)$ \\
\hline-0.772 & 0.357 & 0.513 & -0.231 & 0.056 & 0.202 & 0.083 \\
\hline$(-1.48)$ & $(4.18)$ & $(3.75)$ & $(-2.08)$ & $(0.73)$ & $(3.06)$ & $(1.31)$ \\
\hline \multicolumn{7}{|c|}{$C R$ as a proxy for financial constraints } \\
\hline 0.348 & 0.050 & & & -0.035 & 0.298 & 0.033 \\
\hline$(0.63)$ & $(0.72)$ & & & $(-1.14)$ & $(4.39)$ & $(0.47)$ \\
\hline-0.007 & & 0.303 & & -0.150 & 0.200 & 0.076 \\
\hline$(-0.02)$ & & $(3.42)$ & & $(-0.94)$ & $(3.66)$ & $(1.39)$ \\
\hline-1.133 & 0.312 & 1.180 & -0.845 & 0.037 & 0.217 & 0.069 \\
\hline$(-1.61)$ & $(2.52)$ & $(3.18)$ & $(-2.50)$ & $(0.45)$ & $(3.28)$ & $(1.08)$ \\
\hline \multicolumn{7}{|c|}{$W W$ as a proxy for financial constraints } \\
\hline-1.193 & 0.218 & & & 0.021 & 0.306 & 0.062 \\
\hline$(-1.93)$ & $(2.20)$ & & & $(0.74)$ & $(5.53)$ & $(1.19)$ \\
\hline-0.007 & & 0.303 & & -0.150 & 0.200 & 0.076 \\
\hline$(-0.02)$ & & $(3.42)$ & & $(-0.94)$ & $(3.66)$ & $(1.39)$ \\
\hline 3.617 & -0.196 & -1.532 & 1.867 & -0.237 & 0.212 & 0.080 \\
\hline$(1.66)$ & $(-1.34)$ & $(-2.97)$ & $(3.52)$ & $(-1.64)$ & $(3.86)$ & $(1.68)$ \\
\hline \multicolumn{7}{|c|}{$H P$ as a proxy for financial constraints } \\
\hline 0.407 & -0.000 & & & -0.047 & 0.308 & 0.046 \\
\hline$(1.17)$ & $(-0.00)$ & & & $(-1.52)$ & $(5.34)$ & $(0.87)$ \\
\hline-0.007 & & 0.303 & & -0.150 & 0.200 & 0.076 \\
\hline$(-0.02)$ & & $(3.42)$ & & $(-0.94)$ & $(3.66)$ & $(1.39)$ \\
\hline 0.494 & -0.369 & 0.159 & 0.352 & -0.329 & 0.169 & 0.069 \\
\hline$(1.06)$ & $(-2.35)$ & $(1.08)$ & $(2.15)$ & $(-2.26)$ & $(3.10)$ & $(1.42)$ \\
\hline
\end{tabular}


Table 8: Fama-MacBeth cross-sectional regressions with the interaction term in the good and bad time subsamples

At the end of each month, we split the full sample into the two subsamples of good and bad times. We define a good time as a period that has a negative change in a spread between a ten-year Baa corporate bond rate and a one-year Treasury bill rate, and define a bad time as a period that has a positive change in the spread. For each month, we estimate Fama and MacBeth cross-sectional regressions of monthly excess returns on the proxies of financial constraints $(F C)$, the principal component of liquidity $(P C L I Q)$, the interaction term $(F C \times P C L I Q)$, and the control variables of the market value of equity $(M V)$, book-to-market ratio $(B / M)$, and momentum $(M O M)$. We use asset size $(A T)$, payout ratio $(P R)$, bond rating $(B R)$, commercial paper rating $(C R)$, the WW, and HP indices as the proxies for financial constraints. $F C$ is the actual value of $A T, P R, W W$, or $H P$, one for firms with $B R$ or $C R$, or zero for firms without $B R$ or $C R, P C L I Q$ is the first principal component of three individual liquidity measures, $M V$ is the market value of equity at the end of June of year $t, B / M$ is the ratio of the book value of equity for the fiscal year ending in year $t-1$, divided by the market value of equity at the end of June in year $t-1$ from the CRSP, and $M O M$ is the cumulative compounded stock returns of the previous six months. We winsorize each regressor at the top and bottom $1 \%$ and transform them to have a mean of zero and a standard deviation of one. The corresponding $t$-statistics based on Newey and West's (1987) standard errors are in parentheses. The sample period covers 1985 to 2017 for $B R$ and $C R$ and 1975 to 2017 for the rest.

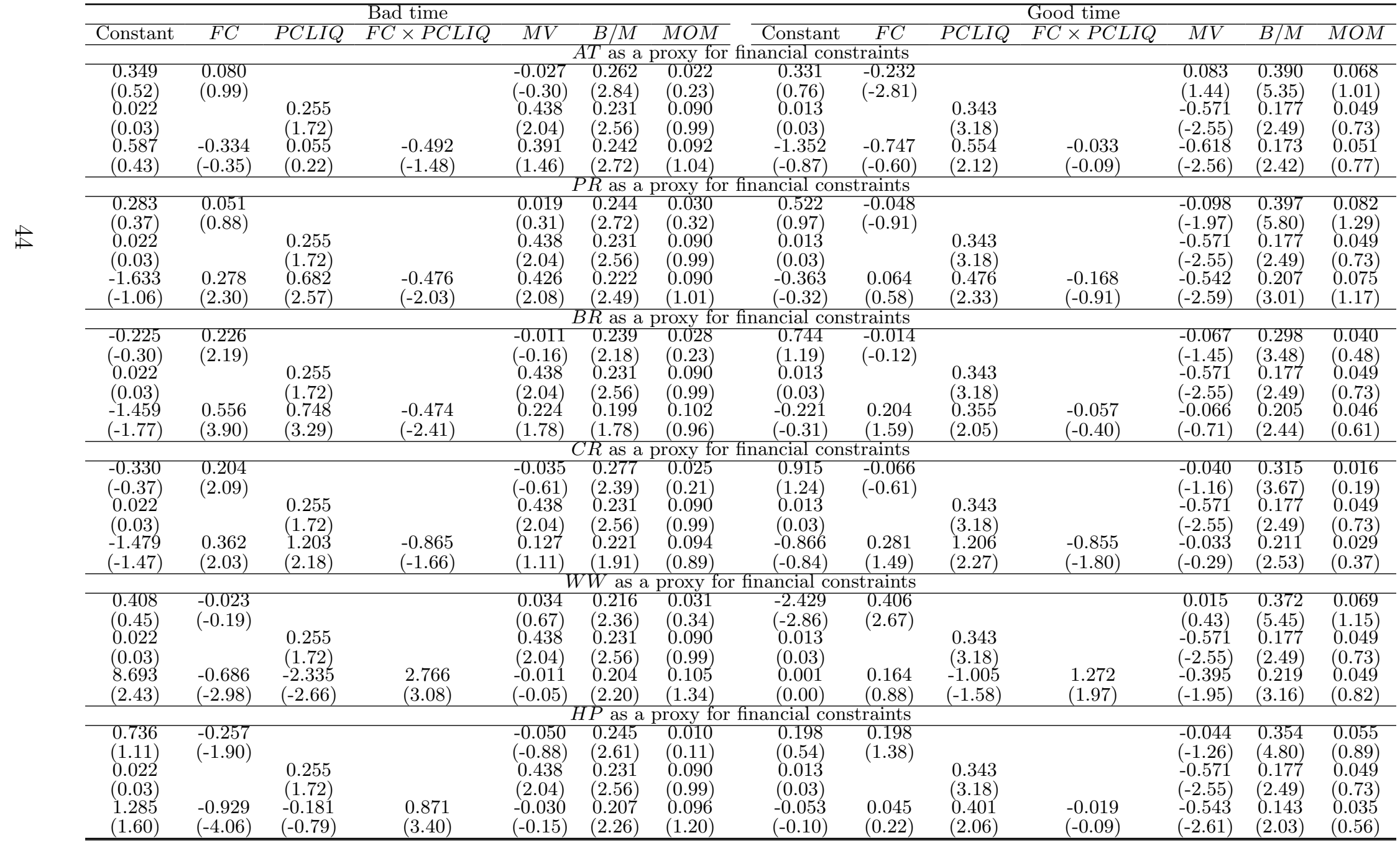

